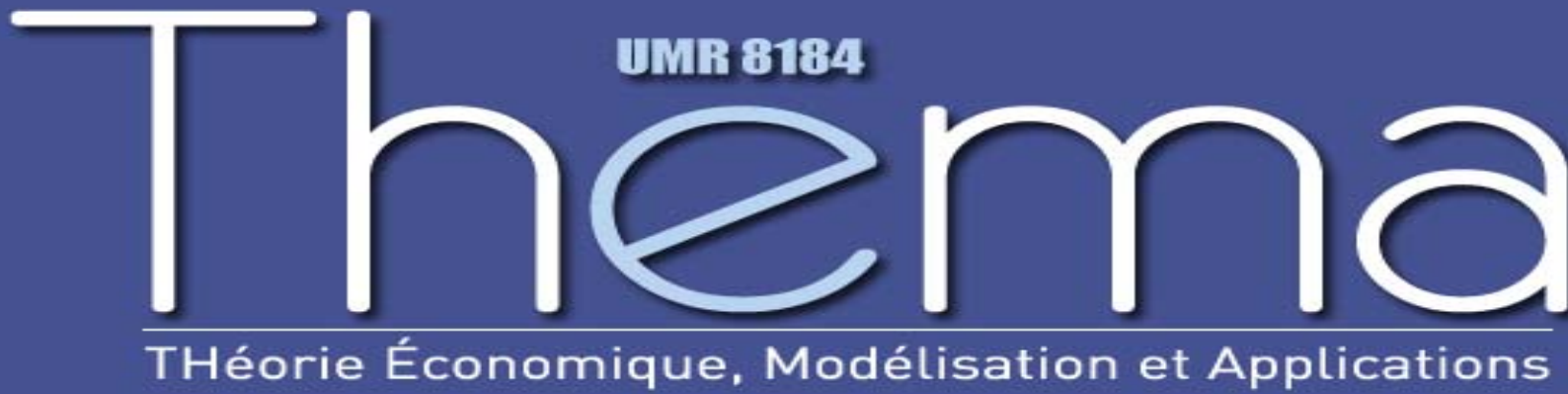

Thema Working Paper $n^{\circ} 2009-05$

Université de Cergy Pontoise, France

Labor Market Frictions

and the International Propagation Mechanism

Lise Patureau

May, 2009 


\title{
Labor Market Frictions and the International Propagation Mechanism
}

\author{
Lise PATUREAU *†
}

June 2009

\begin{abstract}
The paper investigates the determinants of international business cycle comovement in a two-country Dynamic Stochastic General Equilibrium (DSGE) model featured by monopolistic competition and nominal price rigidity, following so the New Open Economy Macroeconomy (NOEM) literature. Within this framework, we assess the role of labor market search and matching frictions in the international propagation of supply and monetary shocks.

Our results show that labor market frictions improve the ability of the New Open Economy Macroeconomy framework to account for international business cycles comovement. In particular, the NOEM model with labor market search is consistent with the international propagation mechanism of monetary shocks identified in the data. Through their impact on labor market dynamics, labor market institutions affect the magnitude of international comovement. Business cycle synchronization is thus found to increase with the generosity of the unemployment benefits system, whereas it decreases with the strictness of employment protection.
\end{abstract}

Keywords: International business cycles, Search, Labor market institutions, Wage bargaining, International transmission of shocks

JEL Classification Number : E24, E32, F41, F42

*Université de Cergy-Pontoise, THEMA, F-95000 Cergy-Pontoise

${ }^{\dagger}$ I am indebted to Thepthida Sopraseuth and Raquel Fonseca for their helpful comments on the paper. I have also benefited from suggestions of the participants of the THEMA seminar. Omissions and mistakes are mine. 


\section{Introduction}

There is a longstanding interest in the determinants of international business cycle interdependence, as attested by the central place devoted to understanding the international propagation of shocks in the traditional international macroeconomics textbooks. The topic has been substantially renewed in the last two decades with the emergence of the international Real Business Cycle (RBC) literature. Incorporating fully micro-founded theoretical grounds in a Dynamic Stochastic General Equilibrium (DSGE) framework, the two-country RBC model of Backus, Kehoe and Kydland (1992) opens the route to promising research in the field of international business cycles. Yet, two limits of this literature may be underlined. First, international RBC models that typically assume flexible prices in a pure walrasian setting fail to account for some key dimensions of international stylized facts. In particular, the predicted cross-country GDP correlation is too low as compared to the data (Backus, Kehoe and Kydland, 1995). Second, and inherently given its "real" nature, this literature faces inability to account for the international transmission of monetary shocks.

Relative to the first point, Hairault (2002) introduces labor market search and matching frictions à la Pissarides (1990) in the international RBC model. He shows the relevance of adding these frictions to better understand the propagation of international fluctuations arising from productivity shocks. Relative to the second point, Kollmann (2001) departs from the Real Business Cycle paradigm to adopt the New Open Economy Macroeconomy (NOEM) framework (Obstfeld and Rogoff, 1995) featured by monopolistic competition and nominal rigidities. Within this framework, he shows the importance of nominal rigidities in the international transmission of monetary and supply shocks. These results point out the role of nominal rigidity in explaining cross-country GDP correlations among OECD countries.

Our paper builds on these references, as we amend the New Open Economy Macroeconomy setting to introduce labor market search and matching frictions. Our contribution to the literature

is then to show the relevance of this framework in the international propagation of supply and nominal shocks and the extent of international business cycles synchronization.

In assessing the ability of the NOEM framework with labor market search to account for international comovement, we adopt the following reasoning. It is well understood that the ingredients of the New Keynesian framework (monopolistic competition and nominal rigidities) are key elements if willing to model the effects of real and nominal shocks, as convincingly established by Kollmann (2001). This framework therefore constitutes the "natural" benchmark to which compare our model's results. To that aim, we develop a version of the model without labor market search, only featuring sticky prices on the monopolistic-competing goods market (denoted "SP" hereafter, for Sticky Price 
model). We then evaluate the performances of our open-economy New Keynesian model with labor market search and matching frictions (denoted "MM" hereafter, for Matching Model) in light of the SP model. This strategy allows us to evaluate the role of labor market frictions in enhancing the international propagation of supply and demand shocks, relative to the vector of international transmission provided by nominal price stickiness.

Some papers have recently introduced labor market search in the New Keynesian framework in a closed-economy setting. Krause and Lubik (2007) reach the conclusion that labor market search and matching frictions do not improve performances of the New Keynesian model regarding output and inflation dynamics. Yet, this view does not make consensus in the literature. Walsh (2005) and Trigari (2004) indeed obtain that the inclusion of labor market search into a New Keynesian framework improves the ability of the model to explain the response of output and inflation along a number of dimensions. Sveen and Weinke (2008) show that combining sticky prices and labor market frictions in a DSGE model contributes to better explain fluctuations in unemployment and vacancies in the occurrence of supply and demand shocks. We pursue this line of research by addressing the question of their relevance regarding international comovement. Campolmi and Faia (2006) and Poilly and Sahuc (2008) also include labor market frictions within the New Open Economy framework. Their objectives differ from ours though, since they focus on the role of crosscountry heterogeneity of labor market institutions on macroeconomic performances of countries within a monetary union. The contribution of Fonseca et al. (2008) is closer to the point addressed here, as they tackle the international business cycle comovement issue. Similarly to Campolmi and Faia (2006) and Poilly and Sahuc (2008) but in contrast to us, they focus on the role of crosscountry divergence in labor market institutions on that topic. Besides, they leave aside the question of monetary shocks and nominal rigidities by sticking to a purely international RBC model.

We develop a two-country DSGE model embedded in the New Open Economy Macroeconomy framework, i.e. featuring monopolistic competition and nominal rigidities on the goods market. Labor markets in each country are subject to search and matching frictions. As in Hairault (2002), fluctuations in labor input result from both changes in hours and changes in employment. We assume that wages and hours are periodically negotiated between firms and workers according to an efficient Nash-bargaining process. Behaviors are affected by labor market institutions in place, captured here through labor taxes and unemployment benefits. ${ }^{1}$

We show that labor market search and matching frictions improve the ability of the New Open Economy Macroeconomy framework to account for international comovement. Our results may be

\footnotetext{
${ }^{1}$ As detailed later in Section 5, we view the job destruction rate as being related to the degree of employment protection. This interpretation leads us to evaluate the role of this dimension of labor market institutions as well.
} 
summed up in three points. First, we show that labor market frictions substantially amplify the responses of the main macroeconomic variables to either supply or monetary impulsions, and in a way consistent with empirical evidence. In quantitative terms, our model better accounts for the effects of money shocks on GDP than the pure New Keynesian framework without labor market frictions. In contradiction with Krause and Lubik (2007) but in line with Trigari (2004) or Walsh (2005), this result confirms the role of labor market frictions in the transmission of monetary policy shocks. Our analysis leads to attribute a significant role to the exogeneity assumption of the job destruction rate combined with the endogenous choice of worked hours in accounting for this result. From this respect, our paper contributes to better understand the divergence of conclusions reached in the literature so far. Second, we show the particular relevance of embedding labor market frictions in the New Keynesian model in an international setting. Introducing labor market frictions indeed enables the NOEM model to be consistent with the international propagation of monetary shocks identified in the data. In quantitative terms, this raises the cross-country correlations of macroeconomic variables, while making the model also consistent with the main labor market cyclical properties. Third, we evaluate the role of product and labor market regulations in business cycle comovement. We notably show that labor market institutions substantially affect the magnitude of international comovement through their impact on labor market dynamics. Besides, the impact is not unequivocal among the dimensions of labor market institutions considered. We thus find that international business cycle synchronization increases with more generous unemployment benefits, while it decreases with the strictness of employment protection. An empirical exercise confirms that these predictions are supported by the data in OECD countries.

The paper proceed as follows. Section 2 presents the building blocks of model. In Section 3, we evaluate the role of labor market frictions within the New Keynesian framework, as a vector of propagation of technological and monetary shocks. Section 4 presents the cyclical properties of the model. Section 5 reports a sensitivity analysis to key parameters of the model, i.e. the degree of nominal price rigidity and those capturing the design of labor market regulations. Section 6 concludes.

\section{The New Open Economy Macroeconomy framework with labor market search}

\subsection{Description of the model}

We build a two-country DSGE model featured by monopolistic competition and sticky prices on the goods market and matching frictions on the labor market. Before developing further, let us 
motivate our modeling choices. First, we retain an efficient Nash-bargaining process, as hours are periodically subject to negotiations between firms and workers. Some recent contributions rather advocate in favor of a right-to-manage setting, where only the real wage is negotiated and firms freely choose hours (Christoffel and Linzert, 2005 notably). There is no consensus in the literature on that point though. As noted by De Walque et al. (2008), if the right-to-manage setting provides good performances from the inflation persistence point of view, it leads to unsatisfactory results regarding the behaviors of key labor market variables. Due to the large flexibility given to firms, labor adjustments mainly occur through the intensive margin channel, implying implausible responses in hours and strongly reducing employment volatility. We thus adopt the efficient Nash-bargaining framework, following so the large bulk of papers in the related literature (Hairault, 2002, Chéron and Langot, 2004, Trigari, 2004, or De Walque et al., 2008, among others). Second, we assume an exogenous job destruction rate. Yet, Den Haan and Watson (2000) suggest that endogenizing this dimension magnifies the output effects of supply shocks, as well as making them much more persistent. Krause and Lubik (2007), Trigari (2004) and Walsh (2005) adopt a similar assumption. Yet, this comes with the drawback that most labor adjustment occurs through the firing channel, which has been recently contested by the empirical findings of Shimer (2007) and Hall (2005). ${ }^{2,3}$ We consequently discard the endogenous job destruction behavior modeling, to assume an exogenous job destruction rate. We come beck further in the analysis on the role of these modeling choices in our results.

The world economy is divided in two countries, country 1 (home) and country 2 (foreign). Infinitely-lived households consume a continuum of differentiated final goods, produced by monopolistic firms distributed over an interval $[0 ; 1]$ in each country. Nominal price rigidity is modeled through quadratic adjustment costs on prices (Rotemberg, 1982). Money is introduced in the model through a cash-in-advance constraint on consumption purchases. The following sections describe the behaviors of the agents.

\subsection{Labor market flows}

In each country, employment is predetermined at each time and changes only gradually as workers separate from jobs at the exogenous destruction rate $s$, or as unemployed agents find jobs. Let $N_{i t}$, $H_{i t}$ and $V_{i t}$, respectively be the number of employed workers, of hirings and the number of new jobs

\footnotetext{
${ }^{2}$ It has to be noted that the results of Shimer (2007) and Hall (2005) are still debated in the literature. See Yashiv (2007).

${ }^{3}$ From a more technical point of view, endogenous job destruction serves to reintroduce some flexibility in the short run in the standard matching model where capital and employment stocks are predetermined, as in Krause and Lubik (2007). However, such an assumption is not needed here given the instantaneous adjustment in worked hours.
} 
made available by firms in country $i$. Then employment in country $i$ evolves according to:

$$
N_{i t+1}=(1-s) N_{i t}+H_{i t} \quad i=1,2
$$

The number of hirings per period is determined by a constant returns to scale matching function (Pissarides, 1990):

$$
H_{i t}=\chi V_{i t}^{\psi}\left(1-N_{i t}\right)^{1-\psi}, \quad 0<\psi<1
$$

with $U_{i t}=1-N_{i t}$ unemployed workers in period 1 (where total labor force is normalized to 1 ). The parameter $\psi$ measures the firm's share in the match and $\chi>0$ is a scale parameter measuring the efficiency of the matching function.

Due to the time-consuming nature of search on the labor market, a vacant job can at best become

productive only one period after time has slipped by. Defining by $\varphi_{i t}=\frac{H_{i t}}{1-N_{i t}}$ the probability to find a job for unemployed workers, the law of motion of employment in country $i$ becomes :

$$
N_{i t+1}=(1-s) N_{i t}+\varphi_{i t}\left(1-N_{i t}\right)
$$

\subsection{Households}

Each country is populated by a large number of identical households whose measure is normalized to one. Each household consists of a continuum of infinitely-lived agents. As frequent in the RBC labor market literature (Andolfatto, 1996, among others), we assume complete income insurance markets. Consequently, the optimal households' behavior is derived using a dynamic program where ex-post heterogeneity on the labor market does not matter: risk-averse households insure themselves fully against heterogeneous wealth positions. We thus derive the optimal workers' decision rules by solving the program of a representative household.

The household's consumption choice can be decomposed into two steps. First, the representative household optimally solves her intertemporal program, facing each period a budget constraint and a cash-in-advance constraint on her consumption expenditures. Second, she determines the allocation of total consumption between domestic and foreign varieties, depending on their relative price and the elasticity of substitution between national varieties $(\xi)$. Within a basket of national variety, the household optimally sets her demand for each differentiated good, depending on its relative price and of the elasticity of substitution $(\eta)$. Based on related empirical evidence, we assume that the elasticity of substitution between goods is lower between domestic and foreign varieties, than between two national varieties (ie, $\xi<\eta$ ).

In what follows, we present the optimizing program of the household in country 1 (that of the foreign household can be inferred by symmetry). We first describe the intratemporal consumption allocation across goods, before determining the intertemporal consumption choices. 
The intratemporal program In each country, the consumption bundle $C_{i t}^{c}$ aggregates across differentiated varieties produced by domestic and foreign firms. The consumption bundle in country 1 is written as:

$$
C_{1 t}^{c}=\left[\kappa^{\frac{1}{\xi}}\left(C_{1 t}\right)^{\frac{\xi-1}{\xi}}+(1-\kappa)^{\frac{1}{\xi}}\left(C_{1 t}^{*}\right)^{\frac{\xi-1}{\xi}}\right]^{\frac{\xi}{\xi-1}}
$$

with $0<\kappa<1$ and $\xi>0.1-\kappa$ represents the share of imported goods in the consumption basket of goods and $\xi$ the elasticity of substitution between domestic and foreign baskets of goods. $C_{1 t}$ and $C_{1 t}^{*}$ respectively denote the amounts of local and imported varieties consumed by the domestic household.

Consumption indexes for each national variety are defined over a continuum of differentiated goods produced by firms in monopolistic competition. For the domestic and foreign varieties consumed in country 1 , they are written as:

$$
\begin{aligned}
C_{1 t} & \left.=\int_{0}^{1}\left[c_{1 t}(z)\right]^{\frac{\eta-1}{\eta}} d z\right]^{\frac{\eta}{\eta-1}} \\
C_{1 t}^{*} & \left.=\int_{0}^{1}\left[c_{1 t}^{*}(z)\right]^{\frac{\eta-1}{\eta}} d z\right]^{\frac{\eta}{\eta-1}}
\end{aligned}
$$

with $\eta$ the elasticity of substitution across goods and $c_{1 t}(z)\left(\operatorname{resp} . c_{1 t}^{*}(z)\right)$ the amount of good $z$ produced by a firm located in country 1 (resp. country 2) and consumed by the domestic household.

Country 1 household's optimal allocation between varieties leads to the following demand functions :

$$
\begin{aligned}
C_{1 t} & =\kappa\left[\frac{P_{1 t}}{P_{1 t}^{c}}\right]^{-\xi} C_{1 t}^{c} \\
C_{1 t}^{*} & =(1-\kappa)\left[\frac{P_{1 t}^{*}}{P_{1 t}^{c}}\right]^{-\xi} C_{1 t}^{c} \\
c_{1 t}(z) & =\left[\frac{p_{1 t}(z)}{P_{1 t}}\right]^{-\eta} C_{1 t} \\
c_{1 t}^{*}(z) & =\left[\frac{p_{1 t}^{*}(z)}{P_{1 t}^{*}}\right]^{-\eta} C_{1 t}^{*}
\end{aligned}
$$

with $p_{1 t}(z)$ (resp. $\left.p_{1 t}^{*}(z)\right)$ the price of variety $z$ produced by a domestic firm (resp. foreign) firm and sold in country 1. $P_{1 t}^{c}$ is the country 1 's consumption price index, $P_{1 t}$ and $P_{1 t}^{*}$ are the expenditureminimizing price index of each domestic and foreign aggregates consumed in country 1. Prices 
indices in country 1 are given by the following equations:

$$
\begin{aligned}
& P_{1 t}^{c}=\left[\kappa\left(P_{1 t}\right)^{1-\xi}+(1-\kappa)\left(P_{1 t}^{*}\right)^{1-\xi}\right]^{\frac{1}{1-\xi}} \\
& P_{1 t}=\left[\int_{0}^{1}\left(p_{1 t}(z)\right)^{1-\eta} d z\right]^{\frac{1}{1-\eta}} \\
& P_{1 t}^{*}=\left[\int_{0}^{1}\left(p_{1 t}^{*}(z)\right)^{1-\eta} d z\right]^{\frac{1}{1-\eta}}
\end{aligned}
$$

We assume that the law of one price holds at the individual firm level, implying that $p_{1 t}^{*}(z)=$ $e_{t} p_{2 t}^{*}(z)$, with $p_{1 t}^{*}(z)$ and $p_{2 t}^{*}(z)$ the prices of foreign variety $z$ sold in the domestic and foreign markets (expressed in local currency) and $e_{t}$ the nominal exchange rate (defined as the price of foreign currency). The law of one price thus holds at the national variety level:

$$
P_{1 t}^{*}=e_{t} P_{2 t}^{*}
$$

The intertemporal program The objective of country $i$ 's household is to maximize her expected intertemporal utility:

$$
E_{0}=\sum_{t=0}^{\infty} \beta^{t} U\left(C_{i t}^{c}, h_{i t}\right)
$$

The instantaneous utility function is specified as:

$$
U\left(C_{i t}^{c}, h_{i t}\right)=\log \left(C_{i t}^{c}\right)+N_{i t} \Gamma^{n} \frac{\left(1-h_{i t}\right)^{1-\xi_{l}}}{1-\xi_{l}}
$$

where the first term is the utility from final good consumption, while the second part represents the disutility from work by supplying $h_{i t}$ units of hours (total time endowment being normalized to unity). $\xi_{l}$ is the inverse of the intertemporal elasticity of substitution of leisure, while $\Gamma^{n}$ measures the relative utility of leisure. In country $i, N_{i t}$ jobs are productive at the beginning of period $t$, which represents the probability of employment for each household's member.

The domestic household maximizes her expected discounted sum of utility flows (6) subject a sequence of three constraints: the law of motion of employment (1), a cash-in-advance constraint on her consumption purchases (7) and her budget constraint (8) :

$$
\begin{gathered}
P_{1 t}^{c} C_{1 t}^{c} \leq M_{1 t} \\
P_{1 t}^{c} C_{1 t}^{c} \quad+M_{1 t+1}+B_{1 t+1}+e_{t} B_{1 t+1}^{*}+P_{1 t}^{c} C A_{1 t} \leq P_{1 t}^{c}\left(1-\tau^{w}\right) w_{1 t} h_{1 t} N_{1 t} \\
+\left(1-N_{1 t}\right) b_{1 t}+R_{1 t} B_{1 t}+R_{2 t} e_{t} B_{1 t}^{*}+M_{1 t}+T_{1 t}+\int_{0}^{1} \Pi_{1 t}(z) d z
\end{gathered}
$$


Equation (8) reports the domestic household's budget constraint. As in Christoffel and Linzert (2005), we assume that when employed, household members receive the wage payments net of direct taxes $\left(\tau^{w}\right)$, while when unemployed they receive unemployment benefits which are evaluated in consumption units $\left(b_{1 t}\right)$. The household's resources are also made of the detention of financial assets. We retain the assumption of incomplete international financial markets, as a large strand of the related literature underlines the role of this assumption in the international transmission of shocks (Kollmann, 2001, among others). Our modeling of financial markets follows Rabanal and Tuesta (2006). We assume that domestic households are able to trade in two nominal riskless bonds denominated in domestic and foreign currency respectively. These bonds are issued by home-country residents in the domestic and foreign currency to finance their consumption. As in Rabanal and Tuesta (2006), we make the simplifying assumption that foreign residents can only allocate their wealth in bonds denominated in foreign currency. We also suppose that households face a cost of taking positions in the foreign bonds market. This assumption allows us to cope with the issue of non-stationarity implied by the incomplete asset markets framework. ${ }^{4}$ Costs on adjusting foreign assets position (denoted $C A_{1 t}$ ) are paid in terms of composite good and scaled by the parameter $\Phi_{B}>0$, according to the following specification:

$$
C A_{1 t}=\frac{\Phi_{B}}{2}\left[\frac{e_{t} B_{1 t+1}^{*}}{P_{1 t}^{c}}\right]
$$

Last, the household enters the period with an initial stock of money $\left(M_{1 t}\right)$. She also receives lump-sum transfers from the government $\left(T_{1 t}\right)$ and the end-of-period profits as the owner of the local firms $\left(\int_{0}^{1} \Pi_{1 t}(z) d z\right)$.

The period's resources are used for consumption, demand for nominal balances $\left(M_{1 t+1}\right)$ and financial assets $\left(B_{1 t+1}\right.$ and $\left.B_{1 t+1}^{*}\right)$, taking into account adjustment costs on foreign assets transactions. As detailed below, each period worked hours and wage (before tax) are the Nash-bargaining result of negotiations between firms and workers. When solving the intertemporal program, the household consequently takes them as given. Her objective is to maximize Equation (6) subject to Equations (1), (7) and (8). The dynamic problem of a typical domestic household can be written as follows:

$$
\mathcal{W}\left(\mathcal{S}_{1 t}^{H}\right)=\max \left\{U\left(C_{1 t}^{c}, h_{1 t}\right)+\beta E_{t} \mathcal{W}\left(\mathcal{S}_{1 t+1}^{H}\right)\right\}
$$

with the household's state variables $\mathcal{S}_{1 t}^{H}=\left\{M_{1 t}, N_{1 t}, B_{1 t}, B_{1 t}^{*}\right\}$. First-order conditions with respect

\footnotetext{
${ }^{4}$ Schmitt-Grohe and Uribe (2003) investigate the quantitative differences implied by alternative approaches in the literature to induce stationarity. They find that all versions deliver virtually identical dynamics at business cycle frequencies.
} 
to $C_{1 t}^{c}, M_{1 t+1}, B_{1 t+1}$ and $B_{1 t+1}^{*}$ are expressed by the following equations:

$$
\begin{aligned}
\lambda_{1 t} & =\beta E_{t}\left(\frac{1}{P_{1 t+1}^{c} C_{1 t+1}^{c}}\right) \\
\lambda_{1 t} & =\beta E_{t}\left(R_{1 t+1} \lambda_{1 t+1}\right) \\
\lambda_{1 t}\left(1+\Phi_{b} \frac{e_{t} B_{1, t+1}^{*}}{P_{1 t}^{c}}\right) & =\beta E_{t}\left(R_{2 t+1} \lambda_{1 t+1} \frac{e_{t+1}}{e_{t}}\right)
\end{aligned}
$$

where $\lambda_{1 t}$ denotes the multiplier associated to the budget constraint.

\subsection{The firms}

The program of an individual firm Firms are distributed over a interval $[0 ; 1]$ in each country. In a monopolistic competition setting, each differentiated firm sets its prices and quantities taking consumption price indices and aggregate demand functions as given. In what follows, we present the program of country 1's firm $z$ (that of a foreign firm can be inferred by symmetry). For notational simplicity, we suppress the $z$ index from now on. Small letters refer to individual variables while capital letters refer to aggregate ones.

Nominal price rigidity is introduced by quadratic costs on adjusting prices, that are written similarly to Ireland (2001). For a country 1's firm $z$, adjustment cost on prices are thus given by:

$$
c p_{1 t}=\frac{\Phi_{P}}{2}\left(\frac{p_{1 t}}{p_{1 t-1}}-\pi_{1}\right)^{2} y_{1 t}, \quad \Phi_{P}>0
$$

with $y_{1 t}$ individual output of firm $z$. As $\pi_{1}$ represents the steady-state gross inflation rate in country 1 , adjustment costs are null at the long term equilibrium. Price adjustment costs are paid in terms of composite good.

The domestic firm $z$ accumulates physical capital according to the following law of motion:

$$
k_{1 t+1}=(1-\delta) k_{1 t}+i_{1 t}^{c}
$$

with $i_{1 t}^{c}$ the investment bundle of firm $z$ and $0<\delta<1$ the depreciation rate. Firms face quadratic costs on changing the capital stock paid in terms of composite good, specified as in Ireland (2001):

$$
c i_{1 t}=\frac{\Phi_{I}}{2} \frac{\left[k_{1 t+1}-k_{1 t}\right]^{2}}{k_{1 t}}, \quad \Phi_{I}>0
$$

Matching frictions on the labor market imply that firms have to post vacant jobs to recruit workers, denoted $v_{1 t}$ for firm $z$ in country 1 , given the cost of job posting $\bar{\omega}$ (paid in terms of composite goods). To preserve homogeneity of demand functions, the various adjustment costs as well as the investment bundle are assumed to have the same CES structure as the consumption one. 
Technologies are identical across countries (up to asymmetric technological shocks) and across firms. The production technology is given by a Cobb-Douglas function. For a domestic firm $z$, it is written as:

$$
y_{1 t}=A_{1 t} k_{1 t}^{\alpha}\left[h_{1 t} n_{1 t}\right]^{1-\alpha} \quad 0<\alpha<1
$$

$n_{1 t}$ is the number of workers in firm $z$, and $h_{1 t}$ the number of worked hours per worker. Technology levels are assumed to follow a joint first-order autoregressive stochastic process:

$$
\begin{aligned}
& \log A_{1 t+1}=\rho_{a} \log A_{1 t}+\rho_{a 12} \log A_{2 t}+\left(1-\rho_{a}-\rho_{a 12}\right) \log \bar{a}+\varepsilon_{1, t+1}^{a}+\psi_{a} \varepsilon_{2 t+1}^{a} \\
& \log A_{2 t+1}=\rho_{a} \log A_{2 t}+\rho_{a 12} \log A_{1 t}+\left(1-\rho_{a}-\rho_{a 12}\right) \log \bar{a}+\varepsilon_{2, t+1}^{a}+\psi_{a} \varepsilon_{1 t+1}^{a}
\end{aligned}
$$

where $\log \bar{a}$ is the mean of the process and $\left\{\varepsilon^{a}\right\}_{t}$ is the vector of innovations serially independent and correlated between countries. We have $E\left[\varepsilon_{1}^{a}\right]=E\left[\varepsilon_{2}^{a}\right]=0$ and $E\left[\varepsilon_{1}^{a}, \varepsilon_{2}^{a \prime}\right]=0$. The parameter $\psi_{a}$ governs the cross-correlation between technological innovations.

Each monopolistic firm $z$ faces a demand function for its goods emanating from both countries. For a domestic firm $z$, it is given by:

$$
y_{1 t}^{d}=\left[\frac{p_{1 t}}{P_{1 t}}\right]^{-\eta} D_{1 t}+\left[\frac{p_{2 t}}{P_{2 t}}\right]^{-\eta} D_{2 t}
$$

with $D_{1 t}$ demand for the aggregate domestic variety coming from domestic agents, and $D_{2 t}$ demand for the aggregate domestic variety coming from the foreign ones. $\frac{p_{1 t}}{P_{1 t}}$ and $\frac{p_{2 t}}{P_{2 t}}$ are the relative prices of the domestic good $z$ with respect to the aggregate domestic variety in the home and foreign countries respectively.

Extending optimal good-demand functions (Equations (2) to (5)) to other good-demand motives, both domestic and foreign demand for domestic variety can be expressed as functions of relative prices and aggregate demands in each country. Demand for good $z$ produced in country 1 can then be re-written as:

$$
y_{1 t}^{d}=\left[\frac{p_{1 t}}{P_{1 t}}\right]^{-\eta}\left[\kappa\left(\frac{P_{1 t}}{P_{1 t}^{c}}\right)^{-\xi} D_{1 t}^{c}+(1-\kappa)\left(\frac{P_{1 t}}{e_{t} P_{2 t}^{c}}\right)^{-\xi} D_{2 t}^{c}\right]
$$

with $D_{i t}^{c}$ representing aggregate demand in country $i(i=1,2)$ :

$$
D_{i t}^{c}=C_{i t}^{c}+I_{i t}^{c}+\bar{\omega} V_{i t}+C I_{i t}+C P_{i t}+C A_{i t}
$$

Aggregate investment $I_{i t}^{c}$ is defined as $\int_{0}^{1} i_{i t}^{c}(z) d z$. Aggregate adjustment costs on capital $\left(C I_{i t}\right)$, on prices $\left(C P_{i t}\right)$ and on international financial transactions $\left(C A_{i t}\right)$ are similarly defined, as well as $\bar{\omega} V_{i t}$, that represents the demand of goods devoted to job posting in country $i .^{5}$

\footnotetext{
${ }^{5}$ Note that $C A_{2 t}=0$ given our assumption that foreign households have no access to international trade in financial assets.
} 
Each individual firm chooses a contingency plan, that maximizes the expected discounted value of the dividends flow. Given its vector of control variables $\mathcal{C}_{1 t}^{F}=\left\{v_{1 t}, k_{1 t+1}, n_{1 t+1}, p_{1 t}, y_{1 t}\right\}$ and of state variables $\mathcal{S}_{1 t}^{F}=\left\{k_{1 t}, n_{1 t}\right\}$, the dynamic problem of each individual firm in country 1 is written recursively as follows:

$$
\mathcal{W}\left(\mathcal{S}_{1 t}^{F}\right)=\max _{\mathcal{C}_{1 t}^{F}}\left\{\begin{array}{c}
p_{1 t} y_{1 t}-P_{1 t}^{c} w_{1 t} h_{1 t} n_{1 t}\left(1+\tau^{f}\right)-P_{1 t}^{c} i_{1 t}^{c} \\
-\bar{\omega} P_{1 t}^{c} v_{1 t}-P_{1 t}^{c}\left[c p_{1 t}+c i_{1 t}\right]+\beta E_{t}\left[\frac{\lambda_{1 t+1}}{\lambda_{1 t}} \mathcal{W}\left(\mathcal{S}_{1 t+1}^{F}\right)\right]
\end{array}\right\}
$$

subject to the technological constraint (13), the demand function (16), the law of motion of physical capital (12), and that of labor force given by:

$$
n_{1 t+1}=(1-s) n_{1 t}+q_{1 t} v_{1 t}
$$

with $q_{i t}=\frac{H_{i t}}{V_{i t}}$ the probability that a vacant job is matched in country $i=1,2.0<\tau^{f}<1$ is the employer's labor tax rate. As domestic firms are hold by the representative household, the discounted rate is the ratio of the multipliers associated with the budget constraint, since that ratio reflects the consumer's variation in wealth.

Let us also define $z_{1 t}$ and the Tobin's $q_{1 t}^{T}$ as:

$$
\begin{aligned}
z_{1 t} & =\frac{1}{1+\mu_{1 t}} \frac{p_{1 t}}{P_{1 t}^{c}} \alpha \frac{y_{1 t}}{k_{1 t}} \\
q_{1 t}^{T} & =1+\Phi_{I} \frac{i_{1 t}^{c}-\delta k_{1 t}}{k_{1 t}}
\end{aligned}
$$

with $\mu_{1 t}$ the mark-up rate over marginal cost. First-order conditions of the firm's program are given by:

$$
\begin{gathered}
q_{1 t}^{T}=\beta E_{t}\left[\frac{\Lambda_{1 t+1}}{\Lambda_{1 t}}\left\{z_{1 t+1}+q_{1 t+1}^{T}-\delta+\frac{\Phi_{I}}{2}\left(\frac{i_{1 t+1}-\delta k_{1 t+1}}{k_{1 t+1}}\right)^{2}\right\}\right] \\
\frac{\bar{\omega}}{q_{1 t}}=\beta E_{t}\left[\frac{\Lambda_{1 t+1}}{\Lambda_{1 t}}\left\{\frac{1}{1+\mu_{1 t+1}} \frac{p_{1 t+1}}{P_{1 t+1}^{c}}(1-\alpha) \frac{y_{1 t+1}}{n_{1 t+1}}-w_{1 t+1} h_{1 t+1}\left(1+\tau^{f}\right)+(1-s) \frac{\bar{\omega}}{q_{1 t+1}}\right\}\right] \\
y_{1 t}+\beta E_{t}\left[\frac{\Lambda_{1 t+1}}{\Lambda_{1 t}} \Phi_{P} \frac{p_{1 t+1}}{p_{1 t}}\left(\frac{p_{1 t+1}}{p_{1 t}}-\pi_{1}\right) y_{1 t+1}\right]=\eta \frac{\nu_{1 t}}{p_{1 t}} y_{1 t}+\Phi_{P} \frac{P_{1 t}^{c}}{p_{1 t-1}}\left(\frac{p_{1 t}}{p_{1 t-1}}-\pi_{1}\right) y_{1 t}
\end{gathered}
$$

with $\nu_{1 t}$ the multiplier associated with the demand function (16) and $\Lambda_{1 t} \equiv P_{1 t}^{c} \lambda_{1 t}$ the domestic household's marginal utility of wealth in real terms.

Equation (18) represents the optimal choice of capital accumulation. Firms invest in physical capital until the cost of investment $\left(q_{1 t}^{T}\right)$ equals the expected return on investment, which is given by the expected resell price of capital, lower than the true marginal productivity by the mark-up 
rate. Equation (19) highlights the trade-off faced by firms regarding job posting. Firms are enticed to post vacant jobs such as the cost of job posting $\left(\frac{\bar{\omega}}{q_{1 t}}\right)$ is equal to the expected return of a match. As well as in Equation (18), the expected marginal return of employment is lower than the true marginal productivity, given the mark-up rate the monopolistic firm can extract. Last, Equation (20) gives the optimal pricing decision of the firm. Absent nominal price rigidity $\left(\Phi_{P}=0\right)$, the mark-up rate is constant, equal to $\mu=\frac{1}{\eta-1}$. As long as firms face adjustment costs on prices $\left(\Phi_{P}>0\right)$ mark-up rates are endogenous and fluctuate following nominal and real perturbations.

Aggregating across firms Given the assumption of symmetry across firms within a country, the aggregate level of capital stock $K_{i t}$, employment $N_{i t}$, vacancies $V_{i t}$ and output in each country $i=\{1,2\}$ are defined as follows:

$$
\begin{aligned}
K_{i t} & =\int_{0}^{1} k_{i t}(z) d z=k_{i t} & V_{i t} & =\int_{0}^{1} v_{i t}(z) d z=v_{i t} \\
N_{i t} & =\int_{0}^{1} n_{i t}(z) d z=n_{i t} & Y_{i t} & =\int_{0}^{1} y_{i t}(z) d z=y_{i t}
\end{aligned}
$$

From now on, we consider aggregate variables in the reasoning, eventually adapting equations to that aim. In particular, the Nash bargaining program will be solved by considering that surplus from matches are shared by the representative household on the one hand, and the representative "aggregate" firm on the other hand.

\subsection{Negotiating the labor contract}

In each country, the labor contract stipulating the real wage and the amount of worked hours is periodically determined via generalized Nash bargaining between individual workers and their firms. In each country, the negotiated labor contract is given by the solution to the Nash criterion:

$$
\max _{w_{i t}, h_{i t}} \Omega_{i t}=\left(\lambda_{i t} \mathcal{V}_{i t}^{F}\right)^{\epsilon}\left(\mathcal{V}_{i t}^{H}\right)^{1-\epsilon}
$$

with $\Omega_{i t}$ the total surplus of a match in country $i, \mathcal{V}_{i t}^{F}=\frac{\partial \mathcal{W}\left(\mathcal{S}_{1 t}^{F}\right)}{\partial N_{i t}}$ the marginal value of a match for a firm and $\mathcal{V}_{i t}^{H}=\frac{\mathcal{W}\left(\mathcal{S}_{1 t}^{F}\right)}{\partial N_{i t}}$ the marginal value for a match for a worker in country $i$. $\epsilon$ denotes the firm's share of a job's value in the bargaining process.

In country 1 , the optimal contract with respect to hours and wage satisfies the following equations: 6

$$
\frac{\Gamma^{n}}{\lambda_{1 t}}\left(1-h_{1 t}\right)^{-\xi_{l}}=\frac{1-\tau^{w}}{1+\tau^{f}} \frac{1}{1+\mu_{1 t}} \frac{P_{1 t}}{P_{1 t}^{c}}(1-\alpha) \frac{Y_{1 t}}{N_{1 t} h_{1 t}}
$$

\footnotetext{
${ }^{6}$ See Chéron and Langot (2004) for a detailed solving of the Nash bargaining problem.
} 


$$
w_{1 t} h_{1 t}=\frac{1-\epsilon}{1+\tau^{f}}\left[\bar{\omega} \theta_{1 t}+\frac{1}{1+\mu_{1 t}} \frac{P_{1 t}^{1}}{P_{1 t}^{c}}(1-\alpha) \frac{Y_{1 t}}{N_{1 t}}\right]+\frac{\epsilon}{1-\tau^{w}}\left[b_{1 t}-\frac{\Gamma^{n}}{\Lambda_{1 t}} \frac{\left(1-h_{1 t}\right)^{1-\xi_{l}}}{1-\xi_{l}}\right]
$$

with $\theta_{i t} \equiv \frac{V_{i t}}{1-N_{i t}}$ labor market tightness in country $i$. The solution of the bargaining process in country 2 can be derived by symmetry.

As reported in Equation (22), hours are bargained so that marginal return of worked hours equates the worker's marginal disutility of labor expressed in terms of real wealth. In the monopolistic setting, the marginal return on hours departs from their marginal productivity, since the monopoly power of firms enable them extract positive rents. Equation (23) shows that the representative worker's wage bill is a weighted average of the worker's contribution to output, plus hiring costs per unemployed workers (first term of RHS of (23)), and the worker's outside options, that are related to the gap between unemployed and employed workers' revenues expressed in terms of real wealth (second term of RHS of (23)). As underlined by Christoffel and Linzert (2005), under efficient Nash-bargaining, any change in wage is accompanied by a change in hours, so that the "true" measure of firms' marginal labor cost is not the real wage, but the household's marginal rate of substitution of consumption and leisure (Equation (22)). Besides, as shown by the presence of $\mu_{1 t}$ in Equation (23), the monopolistic power of firms allows them to drive the real wage down in the bargaining process, since the marginal return of employment is lower than the true employment marginal productivity.

\subsection{Government and central bank}

In each country, the monetary aggregate evolves as:

$$
M_{i t+1}=M_{i t}+X_{i t}
$$

With $X_{i t}$ specified as $X_{i t}=\left(g_{i t}-1\right) M_{i t}$, this implies the following law of motion for money supply:

$$
M_{i t+1}=g_{i t} M_{i t}
$$

with $g_{i t}$ the monetary growth factor in country $i$.

The modeling of central banks' monetary policy is a topic extensively debated. Starting from Taylor's (1993) paper, the literature points out that the actual monetary authorities behavior is correctly approximated by an endogenous interest rate rule. Accordingly, we assume that in each country the central bank gradually adjusts the short-term nominal interest rate $R_{i t}$ in response 
to deviations of output, inflation and money growth from their steady state values $Y_{i}, \bar{\pi}_{i}$ and $g_{i}$ according to the policy rule:

$$
\log \frac{R_{i t}}{R_{i}}=\rho_{r} \log \frac{R_{i t-1}}{R_{i}}+\rho_{\pi} \log \frac{\pi_{i t}}{\bar{\pi}_{i}}+\rho_{y} \log \frac{Y_{i t}}{Y_{i}}+\varepsilon_{r, i t} \quad i=1,2
$$

The serially uncorrelated innovation $\varepsilon_{r}$ is normally distributed with mean zero and standard deviation $\sigma_{r}$. Parameters $\rho_{y}$ and $\rho_{\pi}$ are strictly positive as long as the objective of the central bank is to stabilize inflation and output. As discussed in Clarida et al. (2000), OECD central banks have a tendency to smooth interest rates, which implies $0<\rho_{r}<1$.

This modeling implies that monetary growth factors $g_{i t}$ are endogenous. For a given interest rate set by the central bank in country $i, g_{i}$ adjusts so as to equilibrate the money market given the households' money demand function.

Every period, the government has a balanced budget. The increase in the money supply and tax revenues are transferred to the local household as lump-sum transfers. Transfers $T_{i t}$ endogenously adjust so as to balance country $i$ government's budget constraint:

$$
X_{i t}+\left(\tau^{w}+\tau^{f}\right) N_{i t} w_{i t} h_{i t} P_{i t}^{c}=T_{i t}+\left(1-N_{i t}\right) b_{i t}
$$

with the unemployment benefit level specified as a function of the wage bill in each country:

$$
b_{i t}=u b w_{i t} h_{i t}
$$

with $u b$ the unemployment benefit ratio assumed to be exogenous and constant.

\subsection{Equilibrium}

Absent any idiosyncratic shock, equilibrium is symmetric within a country and all firms set the same price:

$$
p_{1 t}(z)=p_{1 t}(j)=P_{1 t} \quad \text { and } \quad p_{2 t}^{*}(z)=p_{2 t}^{*}(j)=P_{2 t}^{*}
$$

The model is closed by taking into account the equilibrium conditions on the foreign assets market:

$$
B_{1, t+1}^{*}+B_{2, t+1}^{*}=0
$$

and the composite good market:

$$
P_{1 t}^{c} D_{1 t}^{c}+e_{t} P_{2 t}^{c} D_{2 t}^{c}=P_{1 t} Y_{1 t}+e_{t} P_{2 t}^{*} Y_{2 t}
$$

As in Rabanal and Tuesta (2006) or Kollmann (2001), we impose the ex-post equilibrium condition on the domestic assets market, i.e. $B_{1 t+1}=0$. 
Finally, taking into account the different market equilibrium conditions in the households' budget constraint, we obtain the law of motion of financial assets in the home country, that is the evolution of its balance of payments:

$$
e_{t} B_{1 t+1}^{*}-R_{2 t} e_{t} B_{1 t}^{*}=P_{1 t} Y_{1 t}-P_{1 t}^{c} D_{1 t}^{c}
$$

After having transformed the relevant equations so that they become stationary, the long-run equilibrium is determined. Equations are then log-linearized around the steady state according to Farmer's (1993) methodology.

\subsection{Calibration}

Calibration of the structural parameters is made on a quarterly basis. It is reported in Tables 1,2 and 3.

Table 1: Calibration of structural parameters (1)

\begin{tabular}{ccccccccccccc}
\hline \hline$\alpha$ & $\beta$ & $\delta$ & $\kappa$ & $\eta$ & $\xi$ & $\xi_{l}$ & $h$ & $N$ & $\Phi_{I}$ & $\Phi_{P}$ & $\frac{\Phi_{B}}{N X}$ & $\bar{\pi}$ \\
\hline 0.36 & 0.99 & 0.025 & 0.85 & 6 & 1 & 4 & 0.33 & 0.93 & 7 & 20 & 0.0038 & 1 \\
\hline \hline
\end{tabular}

Calibration of $\alpha$ is based on Kydland and Prescott (1982). The discount factor $\beta$ is set to 0.99, which corresponds to a real annual interest rate is equal to $4 \%$. The depreciation rate of capital is about $10 \%$ a year, implying $\delta=0.025$ on a quarterly basis. The steady-state value of imports to GDP $(1-\kappa)$ is set equal to 0.15 consistently with US data, and as in Hairault (2002). The steady-state gross inflation value of $\bar{\pi}$ is (arbitrarily) set to 1. Following Basu and Fernald (1997), we set the mark-up rate of price over marginal cost to 0.2 , implying a value for the price elasticity of demand $\eta$ equal to 6 . For the G7 countries, a vast consensus estimates the elasticity between national varieties $\xi$ between 0 and 1.5. We follow the literature (Corsetti and Pesenti, 2001 among others) by setting $\xi=1$. As in Chéron and Langot (2004) and Hairault (2002), we choose $\xi_{l}=4$ so that the average individual labor supply elasticity is equal to 0.5 , consistently with the bulk of empirical micro-estimates. As standard in the labor market literature, the steady-sate value for hours is set to $h=1 / 3$ (Chéron and Langot, 2004). Based on the empirical results of Lane and Milesi-Ferretti (2001) on major developed countries, $\Phi_{B}$ is calibrated so that $\Phi_{B} / N X=0.0038$, with $N X$ the steady-state value of exports. The capital adjustment costs parameter $\Phi_{I}$ is taken from Patureau (2007), and close to Kollmann (2001), which calibrate the value in order to match the relative volatility of investment in the G7 countries. With regard to the degree of price stickiness $\left(\Phi_{P}\right)$, most empirical papers using macroeconomic data obtain average time intervals between price 
adjustments in the range of one year. However, when disaggregated prices are examined, prices appear to be much more flexible. Bils and Klenow (2004) thus estimate a mean duration of prices of 5 months using US price data. In contrast, but still using micro-data on US prices, Nakamura and Steinsson (2008) estimate that prices change on average every 8 to 11 months. We retain an intermediate value and calibrate $\Phi_{P}$ such that the implied average duration of the price contract amounts to 9 months. ${ }^{7}$

Table 2: Calibration of structural parameters (2)

\begin{tabular}{ccccccc}
\hline \hline$s$ & $u b$ & $\tau^{f}$ & $\tau^{w}$ & $\psi$ & $\epsilon$ & $q$ \\
\hline 0.08 & 0.129 & 0.064 & 0.158 & 0.6 & 0.6 & 0.7 \\
\hline \hline
\end{tabular}

The parameters related to the labor market functioning are calibrated on values commonly used in the literature, mostly based on US data. Their calibration is displayed in Table 2. The weight of vacant jobs in the matching function is set equal to $\psi=0.6$, within the range of reasonable values suggested by Petrongolo and Pissarides (2001). We preserve the Hosios condition by setting $\epsilon=0.6$ as well. As a result, wage and hours bargaining is such that trade externalities on the labor market do not distort equilibrium. However, distortions due to the monopolistic competition setting still remain. The probability that a vacant job is matched is set to 0.7, as in Den Haan and Watson (2000) and Krause and Lubik (2007). The quarterly job destruction rate $s$ is set to 0.08 following Shimer (2005). The unemployment rate is set to 0.12 as in Krause and Lubik (2007). ${ }^{8}$ We calibrate tax rates values $\left(\tau^{f}, \tau^{w}\right)$ and the unemployment benefit ratio $u b \equiv b / w h$ to match the corresponding average values observed in the United-States over the period 1980-2003 (see Appendix A.1 for a detailed description of sources and variables).

Table 3: Calibration of structural parameters (3)

\begin{tabular}{ccccc|cccc}
\hline \hline $\bar{a}$ & $\rho_{a}$ & $\rho_{a 12}$ & $\sigma_{\varepsilon a}$ & $\psi_{a 12}$ & $\rho_{y}$ & $\rho_{\pi}$ & $\rho_{r}$ & $\sigma_{r}$ \\
1 & 0.906 & 0.088 & 0.00852 & 0.13 & 0.5 & 1.5 & 0.7 & 0.0025 \\
\hline \hline
\end{tabular}

Table 3 reports the calibration of the stochastic technological process and the Taylor rule in the model. The technological process parameters are taken from Backus et al. (1995), with the steadystate technology level $\bar{a}$ set to 1 . Parameters $\rho_{y}, \rho_{\pi}$ are calibrated according to the standard Taylor

\footnotetext{
${ }^{7}$ See Keen and Wang (2007) for the mapping between quadratic adjustment costs on prices and Calvo's (1983) type of price stickiness.

${ }^{8}$ As noted by Krause and Lubik (2007), this value is higher than observed unemployment, in order to allow for potential participants in the matching market such as discouraged workers and workers loosely attached to the labor force. This calibration strategy is adopted in a large number of business cycle models with search and matching frictions (see Andolfatto, 1996 or Trigari, 2004, among others).
} 
(1993) rule (and frequently used in the literature, see Christoffel and Küster, 2008 among others). The interest rate smoothing parameter $\rho_{r}$ follows Clarida et al. (2000). The standard deviation of the Taylor rule innovation is based on estimation results obtained by Ireland (2004a), and close to those estimated by Rabanal and Tuesta (2006).

\section{Labor market frictions and the international propagation of shocks}

The objective of the paper is to assess the role of labor market frictions in the international propagation of shocks. This section analyzes the predictions of the model in qualitative terms, i.e. by focusing on the impulse response functions (IRFs hereafter) of main macroeconomic variables to exogenous shocks. We successively analyze the IRFs to total factor productivity (TFP) shocks and to interest rate rule shocks. As exposed in the Introduction, we evaluate the performances of our NOEM model with labor market matching frictions (labeled "MM" hereafter), in light of those achieved by a "pure" New Keynesian version (i.e. featuring monopolistic competition and sticky prices on the goods market but no labor market frictions, labeled "SP" model). IRFs analysis is driven accordingly.

\subsection{IRFs to technological shocks}

Figures 2 and ?? report the responses of main macroeconomic variables in response to a $1 \%$ increase in the home TFP $\left(A_{1}\right)$ in period 1 , in both models. ${ }^{9}$

As noted by Hairault (2002), one limit of the international RBC model refers to its predictions of negative international comovements of labor input and investment in the advent of countryspecific supply shocks. Since capital flows are the primary channel of international transmission, the productivity differential drives investment up in the country positively hit by the total factor productivity shock, and downwards abroad. Employment dynamics reinforces the negative international transmission, as a positive technological shock in one country induces a positive wealth effect at the world level, which implies a decrease in labor supply in the other country. The model based on monopolistic competition and sticky prices also fails on that front, as shown by Figures 2 and ??. The SP model indeed predicts a negative international comovement of worked hours and investment, that are accounted for by similar mechanisms. This is no more the case in the presence of search frictions on the labor market. As reported by Figures 2 and ??, the NOEM model with labor

\footnotetext{
${ }^{9}$ Note that in the SP version, there is no vacant jobs given the absence of labor market search frictions. As well, there is no adjustment through the extensive margin (the number of employed workers), so $N h$ is simply $h$.
} 
Figure 1: Dynamics following a home supply shock (1)
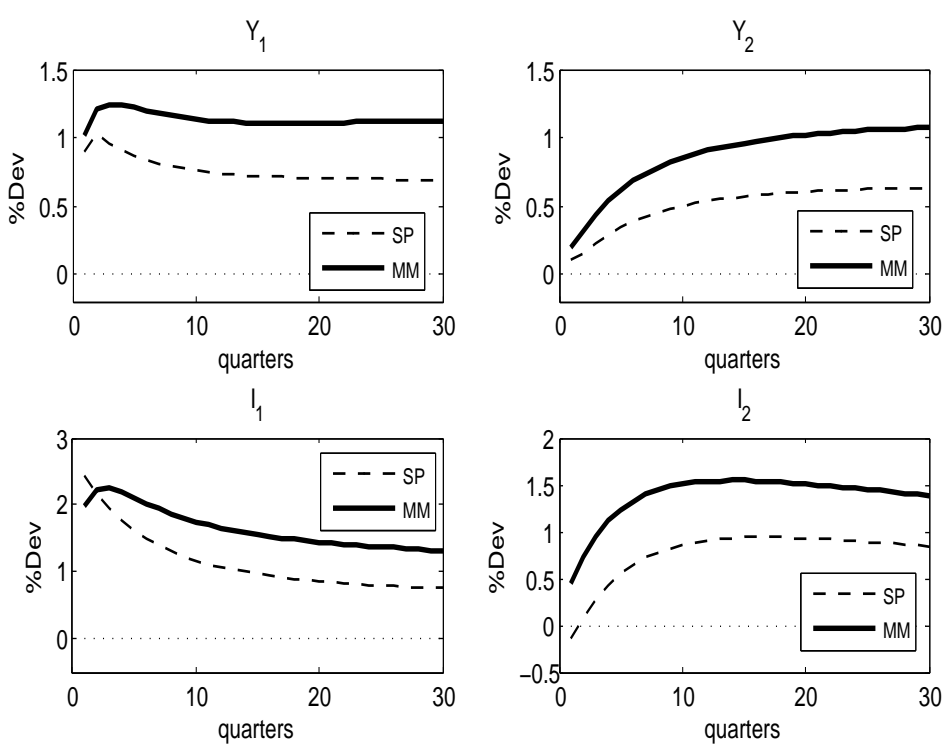

market search predicts positive international comovements in outputs, labor inputs and investments in response to supply shocks. The underlying mechanisms may be summed up as follows.

The immediate increase in domestic production comes from two sources, the direct effect of the rise in TFP and the increase in worked hours. Given the international spillover of the supply shock, similar effects occur in the foreign country. In both countries, and despite the positive wealth effect of the technological shock, households agree to bargain over an increase in worked hours, since it is accompanied by an increase in the real wage. As shown in Figure ??, firms in both countries start opening vacant jobs instantaneously, so as to be able to produce more the second period on through an adjustment at the extensive margin rather than the intensive margin. As a result, from the second period on the negotiated amount of worked hours reduces in both countries because of the positive wealth effect of the supply shock, and labor market adjustment rather occurs through changes in the employment stock. The combined dynamics of the employment stock and individual worked hours explains the gradual increase in total employment in both countries, hence the positive international comovement of total employment.

As in Hairault (2002), the particular dynamics of employment induced by search frictions, interacts with that of investment to account for the positive international comovement of investments as well. Higher employment in the foreign country indeed compensates for the capital outflow due to the negative TFP differential. By increasing the marginal productivity of foreign capital, this mech- 
Figure 2: Dynamics following a home supply shock (2)
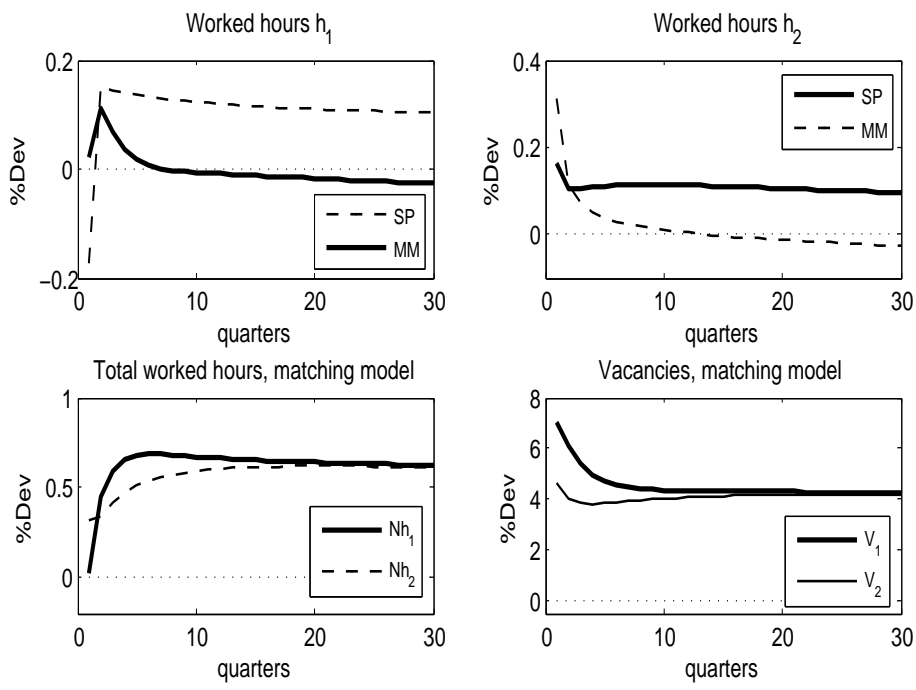

anism leads to a positive international comovement of investments. ${ }^{10}$ This analysis therefore extends Hairault's (2002) results to the NOEM framework. Embedding labor market frictions enables the New Keynesian model to generate positive international comovement of outputs, investments and labor inputs arising from productivity shocks. Next section pursues on this route by gauging their relevance in the international transmission of monetary policy shocks.

\section{$3.2 \quad$ IRFS to monetary shocks}

Figures 3 to 7 thus report the impulse response functions to a $1 \%$ decrease in the domestic interest rate occurring in period 1. IRFs analysis proceeds as follows. We focus on the transmission mechanisms in our NOEM model with labor market frictions. We then highlight the differences in IRFs relative to the sticky-price version of the model ("MM" vs "SP"). We finally confront these predictions to empirical evidence, as it provides us with a way to (eventually) discriminate among the two models.

Labor market frictions and the monetary transmission mechanism The rationale underlying the IRFs of the model with matching frictions is the following.

In the home country, the inflationary effect of the loosening of monetary policy negatively

\footnotetext{
${ }^{10}$ The model also predicts an positive response of consumptions in both countries, the rise being larger in the country directly hit by the shock. The whole set of IRFs are not reported here for sake of space saving, but they are available upon request to the author.
} 
Figure 3: Dynamics of a home monetary policy shock (1)
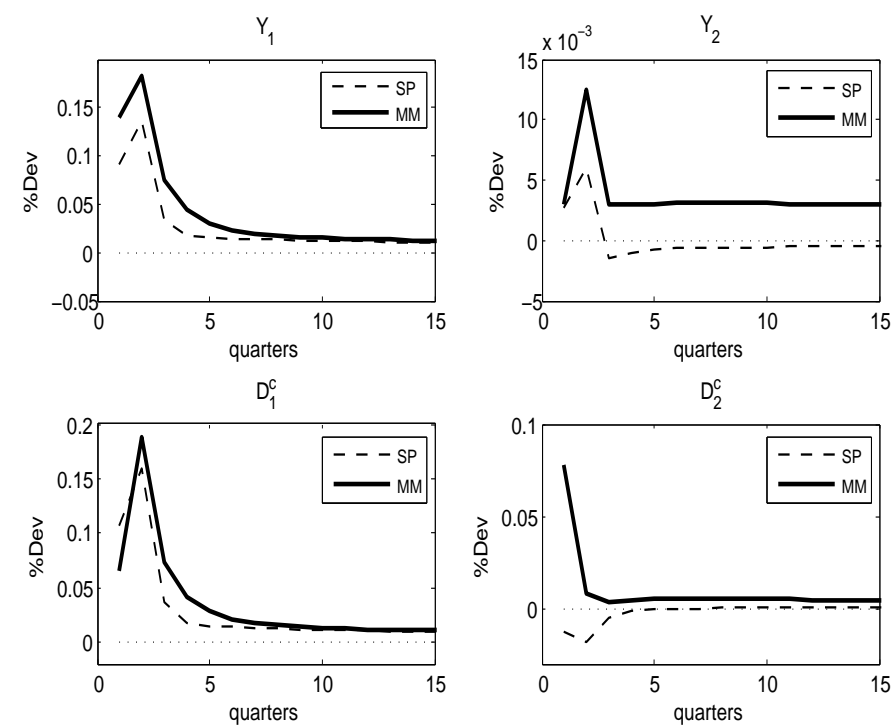

affects domestic consumption given the cash-in-advance constraint. The household escapes the inflationary tax by favoring leisure and investment in physical capital, which leads to an increase in domestic aggregate demand (Figures 3 and 4). The intertemporal smoothing behavior of the household entices her to invest in financial assets as well. Through the external account dynamics, this induces a positive international transmission of the home monetary shock. Foreign consumption and investment increase, and demand for goods rises at the world-wide level.

This expenditure-shifting effect exerts an upward pressure on production in both countries. Conversely, the expenditure-switching effect due to the real exchange rate depreciation (Figure 7) favors domestic production at the expense of foreign one. As shown by Figure 3, the expenditureshifting effect dominates as outputs in both countries increase, leading to a positive comouvement in GDP in response to monetary shocks.

Given expansion in world demand, firms in both countries have a strong incentive to negotiate an increase in worked hours on impact when the shock occurs, given the predetermined levels of employment and capital stocks. Conversely, workers have a strong incentive to bargain a reduction in worked hours, as their outside option increases with the wealth effect. This is particularly the case in the home country, where consumption is hit by the inflationary tax. As displayed in Figure 5, the Nash-bargaining process then results in an increase in worked hours accompanied by an increase in wage, particularly in the home country. The second period on, as soon as employment and capital stocks can be adjusted to production, firms are less willing to accept high wages when negotiating 
Figure 4: Dynamics of a home monetary policy shock (2)
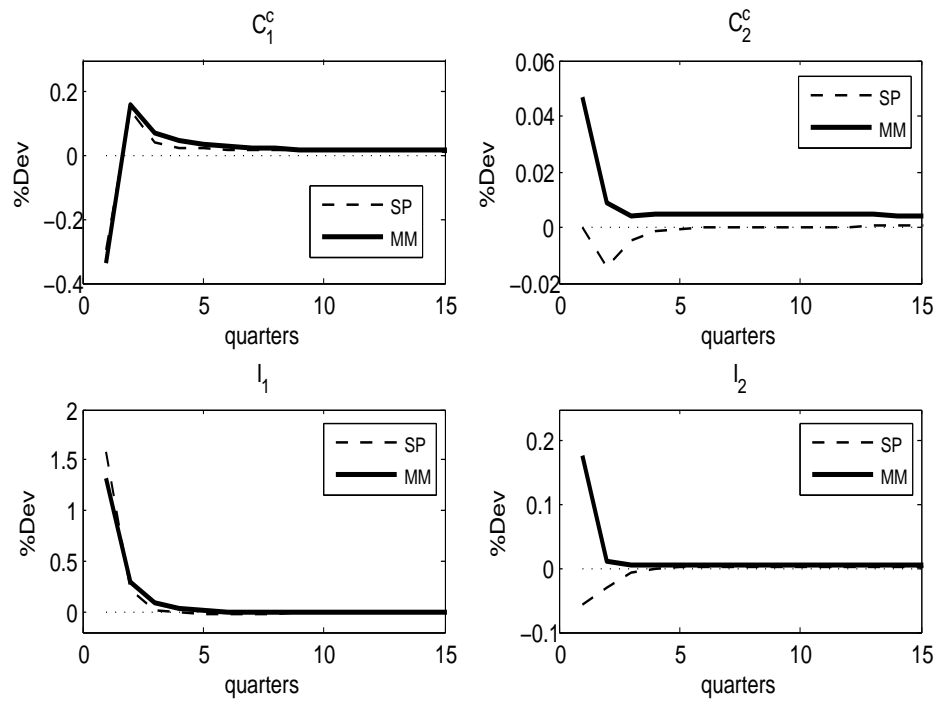

the labor contract, to rather adjust through the extensive margin. This accounts for the decrease in real wage and in worked hours the second period on (Figure 5). This comes at the benefit of an increase in stocks, as shown by the significant rise in capital (given the investment boom on impact) and employment, consecutive to the opening of new vacancies the period of the shock (Figure 5).

Figures 6 and 7 report the IRFS of interest rates, inflation and exchange rates. As shown by Figure 6 , the reduction in the domestic nominal interest rate is accompanied by a similar reduction in the foreign interest rate (even though weaker). The nominal exchange rate depreciation indeed implies a reduction in imports prices in the foreign country. This drives foreign inflation downwards, hence the nominal interest rate given the Taylor rule. Given nominal price stickiness, the reduction in the foreign nominal interest rate outweighs that in inflation. Consequently, real interest rates decrease in both countries (Figure 6). Since the domestic nominal interest rate remains persistently lower than abroad during the transition dynamics, the nominal exchange rate displays an overshooting dynamics consistently with the uncovered interest rate parity, as reported in Figure 7. Depreciation in home currency translates into a real exchange rate depreciation given nominal price stickiness.

IRFs to money shocks: comparing the models What is the role of labor market frictions in the propagation of monetary shocks? As a first answer to this question, we compare the IRFs to the home monetary policy shock predicted by our model ("MM" model) to those obtained in the 
Figure 5: Dynamics of a home monetary policy shock, matching model
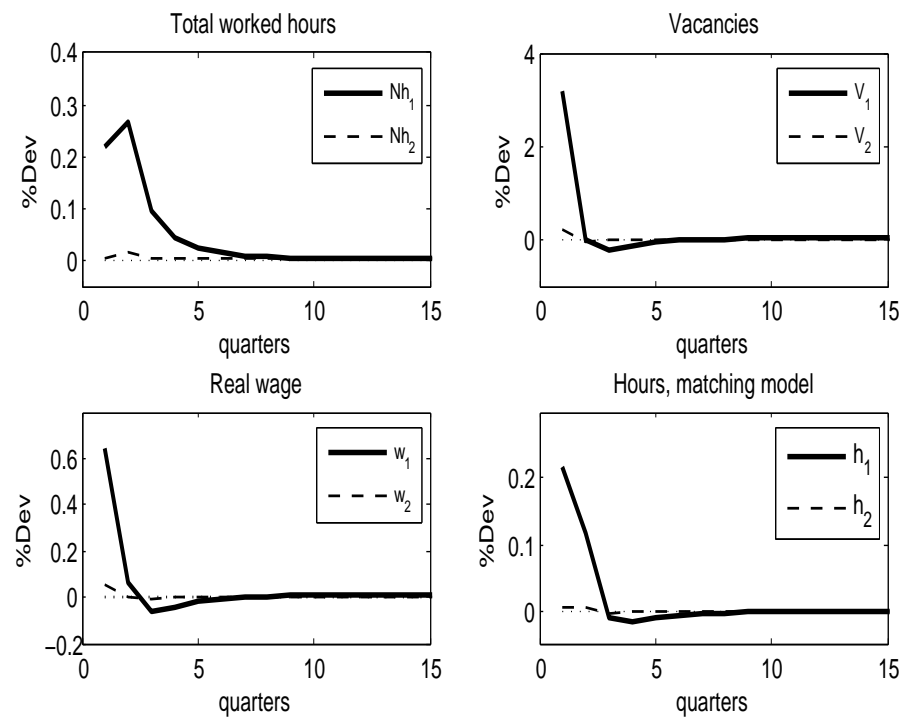

sticky-price version ("SP" model).

Two main results emerge. First, embedding labor market frictions in the New Keynesian model substantially magnifies the effects of monetary shocks. This result emerges from the comparison of responses of macroeconomic aggregates in Figures 3 and 4. This is also the case with respect to exchange rates, as nominal and real depreciations are amplified in presence of labor market frictions (Figure 7). Second, the two models strikingly differ regarding the predicted effects of the home monetary shock abroad. The SP model predicts a negative international comovement of investments and aggregate demands, whereas it is positive when the model incorporates labor market frictions. Further, inflation, nominal and real interest rates increase in the foreign country with the home monetary shock in the SP model, while they decrease in the MM model.

This divergence of results may be related to the current account dynamics. In presence of labor market frictions, the increase in home output outweighs that of home aggregate demand. The resulting surplus of production exported abroad induces a positive wealth effect in the foreign country, leading to a rise in foreign aggregate demand. The opposite occurs in the SP model, where the domestic country has to borrow from abroad to finance her excess of absorption on production. The resulting negative wealth effect in the foreign country drives foreign consumption, investment thus aggregate demand downwards (Figures 3 and 4). Given the home bias in preferences, foreign firms are then enticed to respond to the increase in world aggregate demand driven by the home country by raising mark-up rates rather than quantities. This leads to an increase in prices of 
Figure 6: Dynamics of a home monetary policy shock (3)
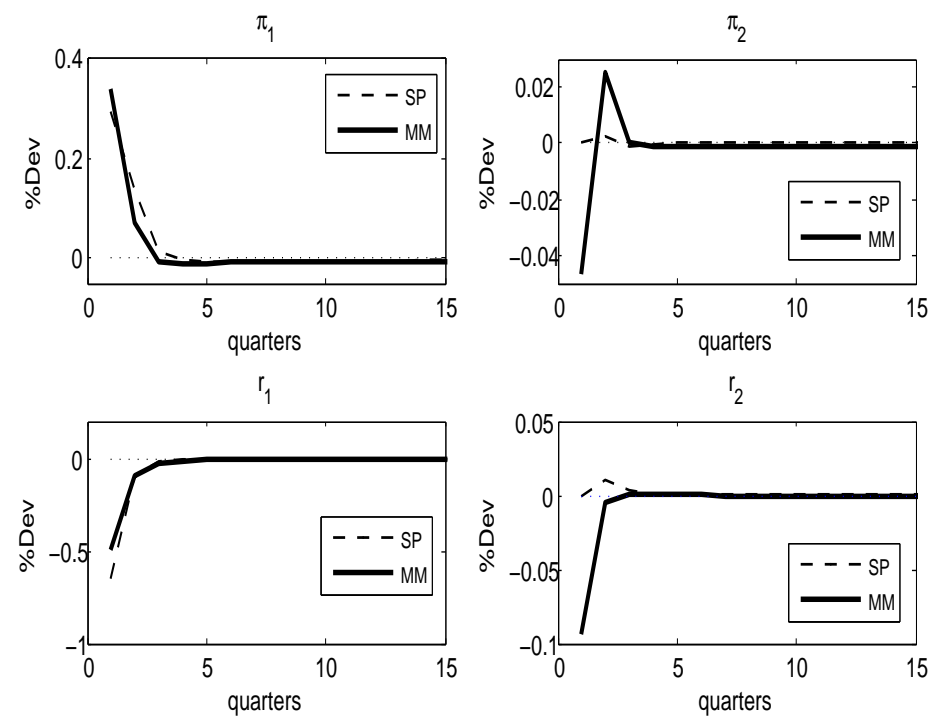

foreign goods, hence in the foreign consumption price index despite the reduction of import prices (Figure 6). Given the increase in both foreign output and inflation, the Taylor rule implies a rise in the foreign nominal interest rate, which also drives the foreign real interest rate upwards (Figure 6 and 7$)$.

IRFs to money shocks: comparing with empirical evidence The question is then, how well do these IRFs fit the data? As underlined by Christiano et al. (1999), despite the various techniques of identifying money shocks, there is a reasonable consensus on the following effects. After a positive monetary shock, output ultimately rises, exhibiting a hum-shape response with a peak value reached at around 6 quarters. Consumption and investment increase, the latter being more responsive to the initial shock, and employment increase after a delay. Kashyap and Mojon (2003) obtain similar VAR results on European countries. On the nominal side, empirical studies typically obtain that inflation goes up in the home country and nominal and real exchange rates depreciate. On the nominal exchange rate response specifically, the literature agrees on evidence of nominal exchange rate overshooting, even though there is little consensus whether this overshooting is delayed or not (see Karamé et al., 2008 for a survey on the topic).

As shown by Figures 3 to 7 , the predictions of the New Keynesian model with labor market frictions are broadly consistent with these empirical results. Two limits may be underlined though. First, consumption contracts with a positive money shock, while it increases in the data. This is 
Figure 7: Dynamics of a home monetary policy shock (4)
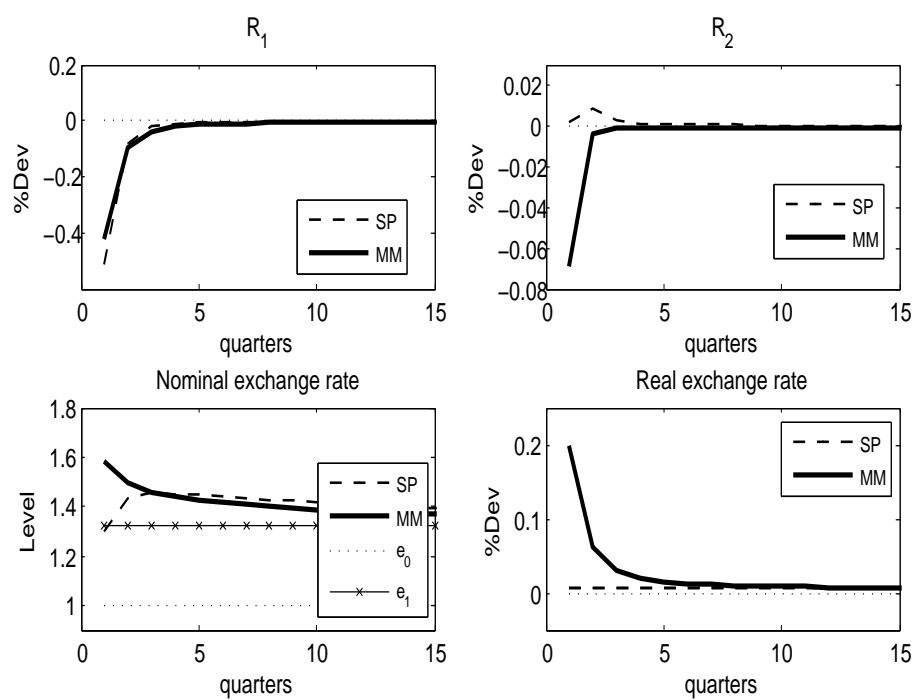

a well-known limit of the models that introduce money through a cash-in-advance constraint, as shown by Christiano (1991) in a closed-economy setting. Second, if the model successfully accounts for the hump-shaped GDP response to the interest rate shock, the degree of persistence is too low as compared to the data (the peak is reached at 2 quarters versus 6 in the data). Despite these limitations, the model with labor market frictions and nominal price rigidity is consistent with related evidence on the empirical effects of monetary shocks. In quantitative terms notably, embedding labor market frictions in the New Keynesian model allows to match the magnitude of the GDP effects of the interest rate shock observed in the data. The peak GDP value is estimated to be equal to half the interest rate change in the USA (Christiano et al., 1999), in Germany and in France (Kashyap and Mojon, 2003) and one third in the Euro area (Kashyap and Mojon, 2003). The sticky-price model performs poorly on that side, predicting a GDP increase by $26 \%$ for a 100 basis point fall in the nominal interest rate. In presence of labor market frictions, this amounts to a $44 \%$ decrease, an order of magnitude in line with the data.

A key issue of the paper is tied to the international propagation of monetary shocks. Using VAR models on the G7 countries, Kim (2001) finds that an US expansionary monetary policy shock raises output, consumption and investment abroad. Besides, this positive spillover effect seems to primarily occur through the world capital market, as the US policy shock induces a decrease in both US and non-US real interest rates, thereby stimulating aggregate demands for goods in both the US and abroad. Schlagenhauf and Wrase (1995) also find evidence of a positive 
international comovement in GDPs in response to a US monetary policy shock, using VAR models on the G7 countries. As shown by the previous IRFs analysis, the model with labor market frictions and nominal price rigidity successfully accounts for the international monetary policy mechanism identified in the data.

This aspect of the international transmission of monetary policy shocks also provides us with a way to discriminate among the two models. If the New Keynesian model correctly accounts for the positive GDP comovement in response to monetary shocks, it yields counterfactual results in a large number of related dimensions. The SP model indeed predicts a rise in the nominal and real interest rates abroad, as well as a negative comovement in aggregate demands, while the opposite is found in the data. The sticky-price model thus does not prove to be consistent with the international transmission mechanism of monetary shocks identified by Kim (2001). Conversely, we show that the inclusion of labor market frictions reconciles the New Open Economy Macroeconomy model with empirical evidence on that front.

\section{A quantitative assessment}

This section analyzes the performances of the model in quantitative terms. Statistics reported in Table 4 are obtained from 500 simulations of the theoretical series that are filtered according to Hodrick and Prescott's (1997) methodology, when the model is subject to technological shocks (column A), to monetary shocks (column B) and to both shocks (column C). Column D reports the same cyclical properties obtained in the sticky-price version of the model (subject to both types of shocks) and Column E those observed on US data (see Appendix A for a detailed description of sources).

With regard to within-country moments The New Keynesian model with labor market search correctly matches the volatility of output, even though it is slightly too low as compared to US data. Labor market frictions and nominal price rigidity play an important role in this result, as they both act as substantial propagation mechanisms of exogenous shocks to output. One the one hand, adding labor market frictions in the sticky-price model increases output volatility substantially (from 1.19\% to $1.58 \%$ in Table 4 ). On the other hand, the MM model predicts a standard deviation of output equal to $1.60 \%$ in the advent of supply shocks, while it amounts to $1.29 \%$ in Hairault's (2002) "pure" RBC model with labor market search but no goods market frictions. ${ }^{11}$ This comparison underlines the relevance of modeling both types of frictions in accounting for output fluctuations.

\footnotetext{
${ }^{11}$ This comparison is relevant as we and Hairault (2002) adopt the same calibration of technological shocks.
} 
Table 4: A quantitative assessment of the model

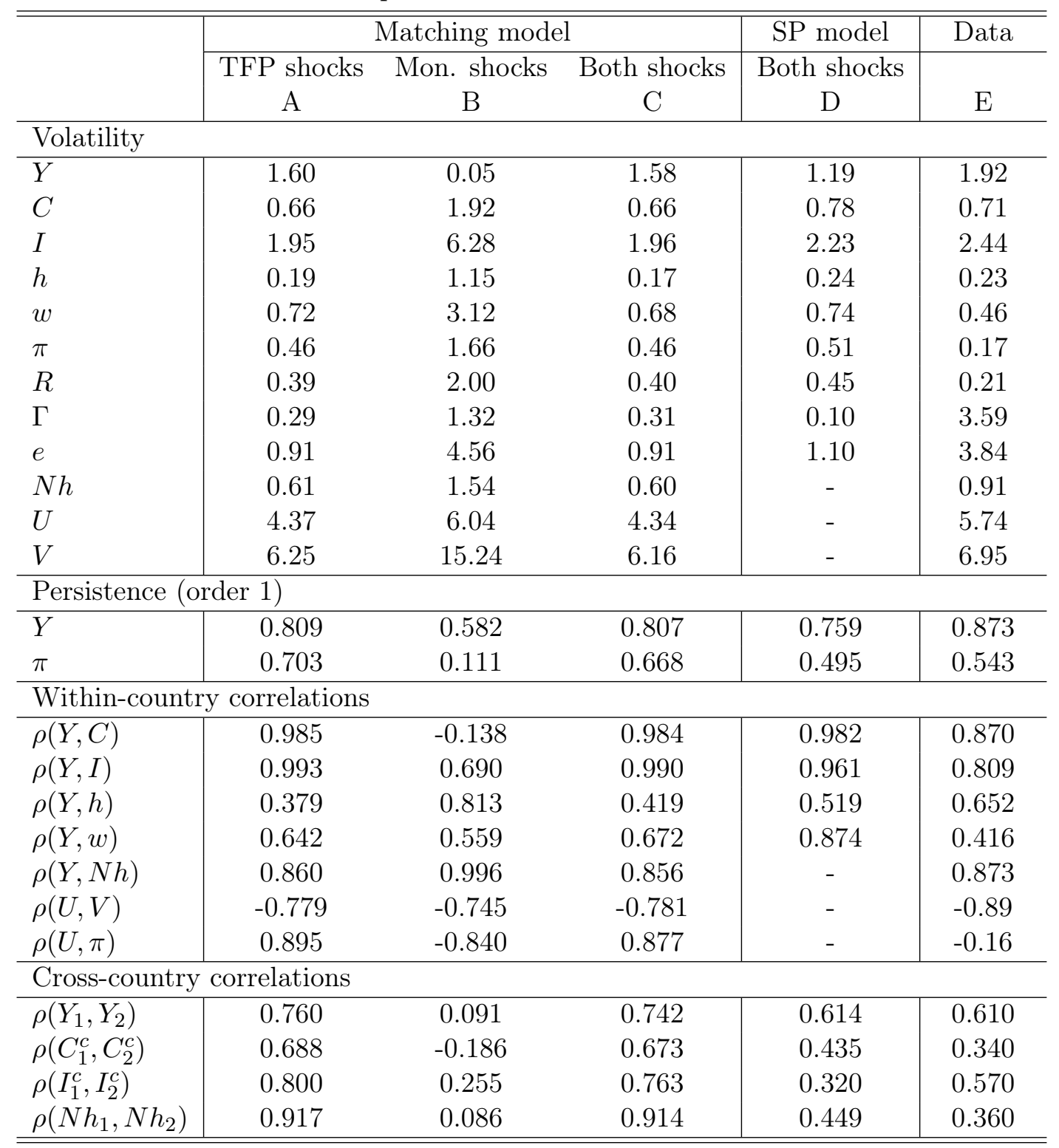

Notes: Simulated moments obtained with 500 simulations. Standard deviations of variables are relative to $Y$. 
Table 4 shows that technological shocks play a leading role in driving GDP fluctuations in the model, while monetary policy shocks have a very limited role. This result is not necessarily surprising given the relatively low standard deviation of the monetary innovation. The limited quantitative importance of the policy shock is also found by Ireland (2004b) and Ireland (2003) in the post-1980 period on US data. This is consistent with the Leeper et al. (1996) view that "most movements in monetary policy instruments are responses to the state of the economy, not random deviations by the monetary authorities from their usual patterns of behavior". As a result, the cyclical behavior of macroeconomic variables is dominated by productivity shocks, as in Krause and Lubik (2007).

The model matches the order of volatility, as investment is more volatile than output, itself more volatile than consumption. It also correctly accounts for the correlation of GDP with the main macroeconomic variables (consumption, investment, employment), even though correlations are slightly too large. Conversely, the model with labor market search underpredicts the volatility and procyclicity of worked hours, and the sticky-price version performs better on this aspect. This result can be accounted for by recalling that all changes should occur through hours in the stickyprice model, given the absence of adjustment possibility at the extensive margin. Besides, this better result on worked hours comes at the expense of deteriorated performances regarding real wage dynamics, which is too volatile and procyclical in the SP model. The presence of labor market frictions improves the performances of the New Keynesian model regarding the cyclical behavior of the real wage, even though it remains too volatile and procyclical as compared to the data. ${ }^{12}$

Moreover, modeling labor market search and matching frictions enables the model to embrace a large number of dimensions of the labor market cyclical behavior, which the sticky-price model is incapable of by nature. This notably contributes to disentangle the behaviors of worked hours and total employment. The model with labor market search thus matches the observed volatility differential between total employment $(N h)$ and hours $(h)$. In that case indeed, most of the variance in total employment takes place through an adjustment at the extensive rather than the intensive margin, consistently with the data. The model also replicates the Beveridge curve (i.e. the negative correlation between unemployment and vacancies jobs), whatever the type of shocks and with an order of magnitude in line with the data. The model's performances are less satisfactory with

\footnotetext{
${ }^{12}$ Hall (2003) and Shimer (2005) have initiated a vivid debate in the literature regarding the role of real wage rigidity. They argue that this mechanism improves the ability of DSGE models to account for the correlation between unemployment and vacancies. Christoffel and Linzert (2005) show that it helps reproducing inflation persistence. This (unsolved) debate leads us to build a variant of the model with real wage rigidity. We find that real wage stickiness reduces volatility of the real wage, while increasing its persistence as well as inflation persistence, consistently with the literature's findings. However, results related to the international comovement issue are left unaffected by the real wage rigidity. For sake of space saving, we consequently do not report these results here. They are available upon request to the author.
} 
respect to the Phillips curve (i.e. the negative correlation between unemployment and inflation). Chéron and Langot (2000) show that embedding monetary shocks in a New Keynesian framework with labor market search frictions allows to also reproduce the Phillips curve. Consistently with their findings, the model generates a negative correlation between unemployment and inflation in response to demand shocks, while it is positive in case of supply shocks. Unlike Chéron and Langot (2000) though, given the relative size of shocks here, when both types of innovations simultaneously occur the correlation between unemployment and inflation is positive, in contradiction with the data.

Krause and Lubik (2007) argue that labor market search and matching frictions do not improve performances of the New Keynesian model regarding inflation and output dynamics. Even more, they find that this framework generates counterfactual labor market dynamics, notably the inability to replicate the Beveridge curve. Our results stand in sharp contrast with this view. As shown by the comparison of Columns $\mathrm{C}$ and $\mathrm{D}$ of Table 4, volatility and persistence in output increase with the inclusion of labor market frictions in the New Keynesian model, therefore bringing the model closer to the data. Further, the MM model generates a substantial degree of inflation persistence, even in the absence of real wage rigidity. Last, Table 4 shows that the model with labor market frictions correctly replicates the Beveridge curve, whatever the nature of shocks. In contrast to Krause and Lubik (2007), our results thus support the findings of Trigari (2004), Walsh (2005) or Sveen and Weinke (2008) in closed-economy frameworks, that labor market frictions improve the performances of the New Keynesian model in matching the dynamics of macroeconomic variables along a large number of dimensions.

This divergence of results can be attributed to the modeling of labor market flows. In Krause and Lubik (2007), the only possibility for firms to adjust idiosyncratic shocks is through the endogenous job destruction rate, as employment is predetermined and there is no intensive margin through worked hours. This modeling may be criticized from both empirical and theoretical aspects. On the empirical side, the role of job destruction flows in accounting for employment fluctuations is highly controversial (see Shimer, 2007 and Hall, 2005). By allowing for this single channel only, Krause and Lubik (2007) attribute an overwhelming role to job destruction flows in comparison to the data. On the theoretical side, the role of job destruction as the single endogenous margin of employment adjustment removes much of the internal propagation mechanisms of labor market search and matching frictions. This feature notably contributes to the major failure of the model in replicating the negative correlation between unemployment and vacant jobs found in the data. These elements thus call for an alternative modeling of labor flows, that widens the set of adjustment possibilities on the labor market. Trigari (2004) and Walsh (2005) preserve the assumption of endogenous job 
destruction but add the ability for firms to modify the employment intensive margin through the amount of worked hours. This limits the magnitude of adjustments occurring through the job destruction rate channel, which notably allows to replicate the Beveridge curve. ${ }^{13}$ In comparison with Trigari (2004) or Walsh (2005), our framework shuts down the endogenous job destruction channel while maintaining adjustments through both worked hours and the employment stock. This joined assumption contributes to account for the ability of the MM model to replicate the Beveridge curve. Trigari (2004) also notes that allowing for labor input variations at the extensive margin reduces the elasticity of real marginal costs to output, which raises persistence in inflation and output responses to exogenous shocks obtained in the New Keynesian model. This result also applies in our framework, as shown in columns $\mathrm{C}$ and D of Table 4. The proximity of our results with those of Trigari (2004) or Walsh (2005) suggests that they would remain robust to the modeling of an endogenous job destruction rate. More broadly, our findings underline the importance of modeling other adjustment channels than job destruction in accounting for the business cycles properties of main labor market and macroeconomic variables. In this appropriate setting, and in contrast to Krause and Lubiks's (2007) view, our results demonstrate the relevance of adding labor market frictions in the New Keynesian model.

With regard to international business cycles properties With regard to exchange rates movements, Table 4 confirms the widespread view that monetary shocks are needed for the model to generate sufficient exchange rate fluctuations. When the model is hit by monetary shocks only, the model correctly matches the relative volatility of the nominal exchange rate. However, the real exchange rate inherits a limited part of it despite the presence of nominal price rigidity. Moreover, the magnitude of nominal and real exchange rates fluctuations is far too low when both supply and nominal shocks occur, in both models. Despite this limitation though, including labor market frictions improves the performances of the NOEM model, as it increases the predicted exchange rates relative volatilities. Consistently with IRFs analysis, labor market frictions amplify the effects of nominal price stickiness on exchange rate movements.

Regarding international comovement of quantities, the New Keynesian model with labor market frictions accounts for the signs of the cross-country correlations of main macroeconomic variables,

\footnotetext{
${ }^{13}$ To understand these results, consider the effects of an expansionary monetary shock. In Krause and Lubik's (2007) framework, firms reduce the job destruction rate in response to the positive demand shock. This implies a fall in unemployment, a rise in labor market tightness, hence a fall in the probability of filling new vacancies. Job creation therefore vanishes. This leads to a concomitant reduction in unemployment $(U)$ and job vacancies $(V)$, in contradiction with the Beveridge curve. By contrast in Trigari (2004) and Walsh (2005), the ability for firms to adjust through worked hours limits the magnitude of adjustments occurring though job destruction. As a result, following a demand shock their models predict a decrease in job destruction and an increase in job creation, therefore replicating the negative correlation between unemployment and job vacancies found in the data.
} 
whatever the type of shocks occurring in the world economy. The only exception is the cross-country correlation of consumption in the advent of monetary shocks. Due to the cash-in-advance constraint, the model predicts a contraction in home consumption altogether with an increase abroad. However when both types of shocks occur, the cross-country correlation of consumption is correctly signed. Table 4 also shows the ability of the model to predict a large cross-country GDP correlation. By contrast, international RBC models typically fail in front of the "quantity puzzle", i.e. they do not capture the high degree of comovement among industrialized countries. The seminal two-country RBC model of Backus et al. (1995) thus predicts a negative cross-country GDP correlation (0.61 in the data). Hairault (2002) and Kollmann (2001) make notable contributions on that topic. Hairault (2002) highlights the role of labor market frictions in enhancing GDP comovement in the occurrence of supply shocks. Kollmann (2001) stresses the importance of nominal rigidities and monetary shocks on business cycle comovement as well. However, none of these models is able to generate enough international interdependence in GDP: the cross-country GDP correlation remains too low, as compared to the data. ${ }^{14}$ Modeling both types of frictions substantially improves the results, as the model does not fail in front of the quantity puzzle. This comforts previous IRFs results, that both types of market frictions are needed in order to account for international business cycle comovement.

Somehow paradoxically, the model even tends to overestimate the degree of international comovement. In most cases, cross-country correlations are too large relative to the data. The sticky-price version of the model performs better on that front, by generating a degree of international comovement closer to stylized facts (even though too large). Yet, we do not view this result as signifying that labor market frictions are not needed to explain the extent of international interdependence. First, our whole set of results (both qualitative and quantitative) show that labor market search frictions substantially complement nominal price rigidity as a key mechanism in the international propagation of shocks. Second, Table 4 shows that cross-country correlations are quite large in the advent of supply shocks, but of a much lower magnitude in case of nominal shocks. Given the relative size of monetary innovations though, cross-country correlations are not substantially lowered when both types of shocks simultaneously occur. Rather than dismissing the importance of labor market frictions per se, we consequently view these results as suggestive of the potential role of adding other sources of shocks in the New Keynesian model with labor market search, which is left for further research.

\footnotetext{
${ }^{14}$ Hairault (2002) reports a cross-country GDP correlation equal to 0.29 (for standard preferences) while it amounts to 0.42 in Kollmann (2001). Besides, both models predict a cross-country correlation in GDP lower than in consumption.
} 


\section{The role of product and labor market regulations}

Previous sections have put into evidence the role of labor market frictions and nominal price rigidity in the international propagation of exogenous shocks. We investigate that point further by assessing how these product and labor market regulations affect the magnitude of international fluctuations. We thus conduct a sensitivity analysis to the values of three related parameters, the price adjustment parameter $\Phi_{P}$, the unemployment benefit ratio $u b$ and the job destruction rate $s$. In doing so, we adopt a broad interpretation of the degree of price stickiness as capturing the extent of product market regulations on the good market. We evaluate the role of labor market institutions in two dimensions, the generosity of the unemployment benefit system and the strictness of employment protection. ${ }^{15}$ The higher the unemployment benefit ratio $u b$, the more generous the unemployment insurance system. We capture the role of employment protection through the job destruction rate value $s$. We indeed interpret a lower job destruction rate (and, more largely, a lower magnitude of job flows), as resulting of more stringent employment protection laws. This view is consistent with a large bulk of empirical papers in the labor market literature showing that stringent employment protection laws reduce job destruction (as well as job creation), as documented by Cahuc and Zylberberg (2004). A similar interpretation of $s$ is made by Christoffel and Linzert (2005). Table 5 reports the results. ${ }^{16}$

Product market regulations As shown in Table 5, product market regulations have a noticeable effect on international comovement. A larger degree of nominal price rigidity (i.e, a higher $\Phi_{P}$ ) raises the cross-country correlation of outputs and investments. This result has also been obtained by Kollmann (2001) in a two-country model with nominal price and wage stickiness. We show that it remains robust to the introduction of other types of market imperfections, notably labor market search and matching frictions. Furthermore, it also holds regarding the predicted cross-country

\footnotetext{
${ }^{15}$ Our framework also allows to gauge the role of labor taxation. We then perform sensitivity analysis to labor taxes $\tau^{w}$ and $\tau^{f}$. We find that heavier tax rates (either on the employer's or the employee's side) tend to increase cross-country correlations of macroeconomic aggregates, as a higher unemployment benefit ratio. This result may be accounted for by similar reasons as for $u b$ (detailed below), since heavier taxes also favor adjustment through the extensive margin. However, for values of tax rates that lie within an empirically plausible range, the quantitative effects on international comovement are much less significant than for $u b$. We consequently do not report the results here, to focus on the role of the unemployment benefit system. Results are available upon request.

${ }^{16}$ In Table 5, the highest calibrated value of $u b$ reproduces the value of the ratio observed in France, while the lowest value corresponds to US data. The highest calibrated value of $s(0.08)$ implies a probability of finding a job for an unemployed worker $\phi=s N /(1-N)$ in steady-state in line with the observed mean duration of unemployment in the US, equal to 4 months (over the period 1973-1998, based on data provided by the OECD). The lowest calibrated value of $s$, corresponding to the highest degree of employment protection, is based on the estimates of Algan et al. (2003) on French data. This calibration is consistent with the mean duration of unemployment observed in France over 1973-1998, of around one year.
} 
Table 5: Product and labor market regulations and GDP comovement: the model's predictions

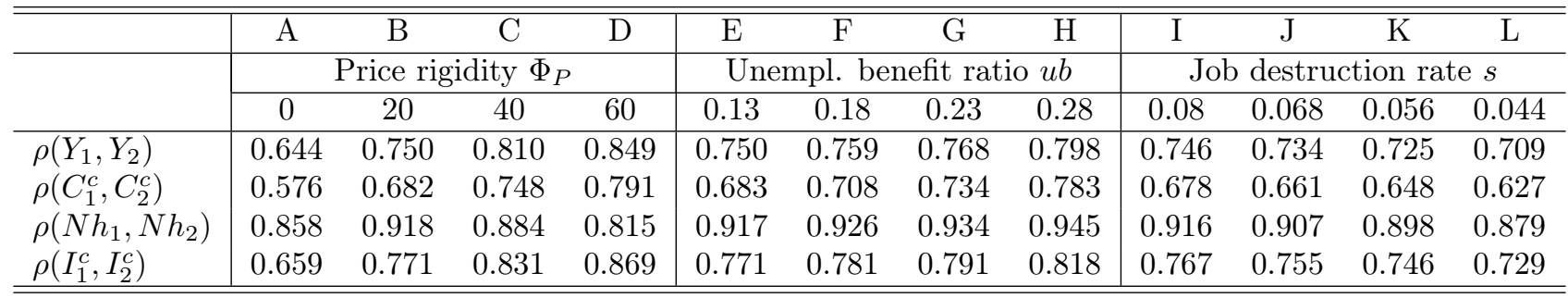

Notes: Simulated moments obtained with 500 simulations of monetary and technological innovations.

correlation of consumption. While product market regulations have no substantial impact on the cross-country correlation of labor inputs, they contribute to enhance international comovement in the various components of aggregate demands, as well as of outputs.

Generosity of the unemployment benefit system As shown in Table 5, a more generous unemployment benefit system (i.e, a higher unemployment benefit ratio $u b$ ) substantially raises international comovement of the main macroeconomic aggregates. As the workers' outside option improves in the bargaining process, households are more reluctant to changes in wage and hours, and adjustment to exogenous shocks occurs more through the extensive margin in both countries. Given the time-consuming nature of search on the labor market, this induces more persistent responses of total employment and output. In quantitative terms then, the more generous unemployment benefits, the larger the extent of international business cycles comovement. ${ }^{17}$

The degree of employment protection laws Conversely, Table 5 shows that more employment protection (i.e. a lower job destruction rate) reduces the cross-country correlations of outputs, labor inputs and aggregate demands components. More employment protection limits the magnitude of job creation flows in response to exogenous shocks. Firms in both countries then favor adjustments to either supply or demand shocks through the intensive margin rather than the extensive margin. Since the amount of worked hours is negotiated with households whose situation differs among countries hit by asymmetric shocks, more stringent EPL thus implies more divergent responses in worked hours across countries. Given the limited responses of the employment stock, this leads to more divergent and dampened responses of total employments and outputs across countries. In quantitative terms, a higher degree in employment protection then results in lower cross-country

\footnotetext{
${ }^{17}$ This mechanism is strengthened by wealth effects. More generous unemployment benefits indeed raise the wealth effect induced either by supply or demand shocks in both countries whatever the country hit by the shock, consistently with previous IRFs analysis. In case of positive shocks for instance, the sustained rise in world aggregate demand induces more positive responses of outputs in both countries.
} 
correlations of the main macroeconomic variables. This result is in line with the empirical findings of Artis et al. (2008) and Fonseca et al. (2008), which obtain that a higher degree of employment protection significantly reduces the cross-country GDP correlation among OECD countries.

Assessing the role of labor market institutions leads the following comments. First, the fact that both dimensions of labor market institutions substantially affect the magnitude of international comovement, confirms the role of labor market frictions in the international propagation of shocks. Second, we show that the design of labor market regulations per se matters in the extent of international comovement. The level of labor market institutions indeed affects the economy's response to her own country-specific shocks, as well as to foreign shocks. The effect is notably tied to the way labor market regulations modify the magnitude of adjustments occurring through the extensive margin relative to the intensive margin on the labor market. Previous reasoning suggests that international comovement is enhanced when labor market adjustments occur primarily through the extensive margin. As a result, since the various dimensions of labor market institutions have differentiated effects on these adjustments, they have differentiated impacts on the degree of international interdependence as well. International business cycle comovement is thus found to increase with more generous unemployment benefits raise, while it is reduced by stringent employment protection.

Empirical assessment One can then wonder whether these predictions are confirmed by the data. To verify this point, we empirically evaluate the effects of product and labor market regulations on the extent of business cycle synchronization within 20 OECD countries over the period 1964:12003:4. Business cycle comovement is captured by the cross-country GDP correlation calculated over the whole period for all country pairs (190 observations). We capture the role of labor and product market regulations using information contained in the Economic Freedom database provided by the Fraser Institute (Gwartney and Lawson, 2006). Precisely, we evaluate the effects of the unemployment benefits generosity (denoted "Unempl. Ben. Index" hereafter), the strictness of employment protection laws ("EPL Index") and the extent of price controls ("Price Rig. Index"). For each dimension and for each country pair $(i, j)$, we use the sum of the two countries' institutional variables as our bilateral indicator of the extent of regulation within the pair, as in Artis et al. (2008). Given the variables' construction in the Economic Freedom database, the higher the bilateral indicator, the lesser the extent of regulation.

We evaluate the empirical effects of product and labor market regulations on cross-country GDP correlation using OLS regressions written as:

$$
\rho_{i j}^{y}=\alpha+\beta \operatorname{Reg}_{i j}+\gamma X_{i j}+\mu_{i}+\mu_{j}+\epsilon_{i j}
$$


where $\rho_{i j}^{y}$ denotes the cross-counrty GDP correlation and $\operatorname{Reg}_{i j}$ measures the extent of regulation (in one of the three dimensions considered). We ensure the robustness of the link by adding a set of control variables in the regression to eliminate potential omitted variables bias. The estimated equation thus always includes country fixed effects $\left(\mu_{i}\right.$ and $\mu_{j}$ in Equation (29)). Depending on the specification, it may also include a set of observable control variables that are likely to affect international comovement $\left(X_{i j}\right.$ in Equation (29)). Even though there is no consensus in the literature on the key determinants of business cycles comovement, most related empirical papers acknowledge a major role to bilateral trade (Frankel and Rose, 1998, Baxter and Kouparitsas, 2005 or Artis et al., 2008 among others). We accordingly retain this dimension here (denoted "Bilateral trade" in Table 6). We also include in the $X_{i j}$ set a dummy variable controlling for business cycle synchronization between countries that joined the European Monetary Union in 1999 (denoted "Dummy EMU" hereafter). Details on variables and sources are provided in Appendix A. Empirical results are reported in Table 6 .

Table 6: Product and labor market regulations and GDP comovement in the data

\begin{tabular}{l|ccc|ccc|ccc}
\hline \hline \multirow{2}{*}{ Model : } & \multicolumn{7}{|c}{ Dep. Variable: cross-country GDP correlation } \\
\cline { 2 - 10 } & $(\mathrm{A})$ & $(\mathrm{B})$ & $(\mathrm{C})$ & $(\mathrm{D})$ & $(\mathrm{E})$ & $(\mathrm{F})$ & $(\mathrm{G})$ & $(\mathrm{H})$ & $(\mathrm{I})$ \\
\hline Unempl. Ben. Index & $-0.206^{a}$ & $-0.200^{a}$ & $-0.193^{a}$ & & & & & & \\
& $(0.032)$ & $(0.031)$ & $(0.025)$ & & & & & & \\
EPL Index & & & & $0.053^{a}$ & $0.054^{a}$ & $0.049^{a}$ & & & \\
& & & & $(0.016)$ & $(0.023)$ & $(0.050)$ & & & \\
Price Rig. Index & & & & & & & $-0.162^{a}$ & $-0.158^{a}$ & $-0.152^{a}$ \\
& & & & & & & $(0.025)$ & $(0.024)$ & $(0.020)$ \\
\hline Bilateral trade & & $0.053^{b}$ & $0.046^{b}$ & & $0.053^{b}$ & $0.046^{b}$ & & $0.053^{b}$ & $0.046^{b}$ \\
& & $(0.023)$ & $(0.021)$ & & $(0.015)$ & $(0.021)$ & & $(0.023)$ & $(0.021)$ \\
Dummy EMU & & & $0.091^{c}$ & & & $0.091^{c}$ & & & $0.091^{c}$ \\
& & & $(0.050)$ & & & $(0.016)$ & & & $(0.050)$ \\
\hline Obs. & 190 & 190 & 190 & 190 & 190 & 190 & 190 & 190 & 190 \\
$R^{2}$ & 0.59 & 0.62 & 0.63 & 0.59 & 0.62 & 0.63 & 0.59 & 0.62 & 0.63 \\
\hline \hline
\end{tabular}

Notes: Robust standard errors in parentheses with ${ }^{a b}$ and ${ }^{c}$ respectively denoting significance at the $1 \% 5 \%$ and $10 \%$ levels. Country fixed effects included.

As shown in Table 5, the model predicts that a more generous unemployment benefit system and a larger degree of price stickiness increase the cross-country GDP correlation. Conversely, more stringent employment protection laws should reduce business cycle synchronization. In terms of Equation (29), we thus expect negative signs for the $\beta$ coefficients respectively associated with the Unemployment Benefit Index (Columns (A) to (C)) and the Price Rigidity Index (Columns (F) to $(\mathrm{H})$ ), and a positive sign for the $\beta$ coefficient associated with the EPL Index (Columns (C) to (E)).

Results reported in Table 6 confirm the empirical relevance of the model's predictions. The estimated coefficients associated with product and market regulations are significant and of expected 
sign. Besides, their effects on GDP comovement are robust to the inclusion of unobservable and observable control variables. When included, bilateral trade and adhesion to EMU are also estimated significant and of expected (positive) sign, as more bilateral trade and adhesion to EMU are usually found to enhance business cycle comovement in the empirical literature (see Baxter and Kouparitsas, 2005 or Artis et al., 2008 notably). Table 6 thus provides an empirical support to our theoretical predictions, that more generous unemployment benefits raise international business cycle comovement, while more stringent employment protection has the opposite effect.

\section{Conclusion}

This paper amends the New Open Economy Macroeconomy setting based on monopolistic competition and nominal rigidity, to introduce labor market search and matching frictions. We evaluate the ability of this framework to account for the international propagation of shocks and international business cycle synchronization.

Our results indicate that labor market search and matching frictions improve the ability of the New Open Economy Macroeconomy framework to account for international business cycle comovement. In particular, they enable the NOEM model to be consistent with the international propagation mechanism of monetary shocks identified in the data. In quantitative terms, they enhance the magnitude of cross-country GDP correlation, while making the NOEM model also consistent with main labor market cyclical properties. We also show that the design of labor market policies matters. Yet, their impact is not unequivocal among the various dimensions of labor market institutions, given their differentiated effects on labor market dynamics. The extent of international comovement is thus found to increase with the generosity of the unemployment benefits system, whereas it decreases with the strictness of employment protection. We conduct an econometric exercise using data on OECD countries, which provides an empirical support to these predictions.

These results open the route to further enlargements. First, the cyclical behavior of the model's variables remains dominated by productivity shocks. This implies some unsatisfactory results, notably too large predicted cross-country correlations of macroeconomic variables as compared to the data. This suggests to introduce other types of demand shocks beyond monetary policy shocks. Second, sensitivity analysis indicate that the design of labor market policies affects the international propagation of shocks, but not with a similar fashion depending of the dimension of labor market

institutions. This suggests to tackle the question in normative terms, asking for the "good design" of labor market institutions in terms of welfare analysis. These points are left for further research. 


\section{References}

Algan, Y., Hairault, J. and Langot, F. (2003), 'Wealth effect on labor market transitions', Review of Economic Dynamics 6, 156-178.

Andolfatto, D. (1996), 'Business cycles and labor-market search', The American Economic Review (1), 112-132.

Artis, M., Firdmuc, J. and Scharler, J. (2008), 'The transmission of business cycles', Economics of Transition 16(3), 559-582.

Backus, D., Kehoe, P. and Kydland, F. (1992), 'International real business cycles', Journal of Political Economy 100(4), 745-775.

Backus, D., Kehoe, P. and Kydland, F. (1995), International real business cycles: Theory versus evidence, in T. Cooley, ed., 'Frontiers of Business Cycle Research', Princeton University Press, pp. 213-231.

Basu, S. and Fernald, J. (1997), 'Returns to scale in u.s. production: Estimates and implications', Journal of Political Economy .

Baxter, M. and Kouparitsas, M. (2005), 'Determinants of business cycle comovement: A robust analysis', Journal of Monetary Economics 52, 113-157.

Bils, M. and Klenow, P. J. (2004), 'Some evidence on the importance of sticky prices', Journal of Political Economy 112(5), 947-985.

Cahuc, P. and Zylberberg, A. (2004), Labor Economics, MIT Press, Cambridge, MA.

Calvo, G. (1983), 'Staggered prices in a utility-maximizing framework', Journal of Monetary Economics 12, 383-398.

Campolmi, A. and Faia, E. (2006), Cyclical inflation divergence and different labor market institutions in the emu, Working Paper 619, European Central Bank.

Chari, V., Kehoe, P. and McGrattan, E. (2002), 'Can sticky price models generate volatile and persistent real exchange rates?', Review of Economic Studies 69(3), 533-563.

Chéron, A. and Langot, F. (2000), 'The Phillips and Beveridge curves revisited', Economic Letters p. $371-376$.

Chéron, A. and Langot, F. (2004), 'Labor market search and real business cycles: reconciling nash bargaining with the real wage dynamics', Review of Economic Dynamics pp. 476-493.

Christiano, L. (1991), 'Modeling the liquidity effect of a money shock', Federal Reserve Bank of Minneapolis Quarterly Review 15, 3-34.

Christiano, L., Eichenbaum, M. and Evans, C. (1999), Monetary policy shocks: What have we learned and to what end?, in R. Taylor and M. Woodford, eds, 'Handbook of Macroeconomics', Vol. 1A, Elsevier North Holland, pp. 65-148. 
Christoffel, K. and Küster, K. (2008), 'Resuscitating the wage channel in models with unemployment fluctuations', Journal of Monetary Economics 55(5), 865-887.

Christoffel, K. and Linzert, T. (2005), The role of real wage rigidity and labor market frictions for unemployment and inflation dynamics, ECB Working Paper 556.

Clarida, R., Gali, J. and Gertler, M. (2000), 'Monetary policy rules and macroeconomic stability: Evidence and some theory', The Quarterly Journal of Economics 115, 147-180.

Corsetti, G. and Pesenti, P. (2001), 'Welfare and macroeoconomic interdependence', Quarterly Journal of Economics 116(6307), 421-446.

Darvas, Z., Rose, A. and Szarpary, G. (2005), Fiscal divergence and business cycle synchronization : Irresponsibility is idiosyncratic, Working paper 11580, NBER.

De Walque, G., Pierrard, O., Sneessens, H. and Wouters, R. (2008), Sequential bargaining in a newkeynesian model with frictional unemployment and staggered wage negotiation, BCL Working Papers 33, Central Bank of Luxembourg.

Den Haan, W. Ramey, G. and Watson, J. (2000), 'Job destruction and propagation of shocks', American Economic Review 90, 482-498.

Farmer, R. (1993), The Macroeconomics of Self-fulfilling Prophecies, MIT Press, Cambridge,MA.

Fonseca, R., Patureau, L. and Sopraseuth, T. (2008), Divergence in labor market institutions and international business, Working Paper 2008-14, THEMA.

Frankel, J. and Rose, A. (1998), 'The endogeneity of the optimum currency area criteria', Economic Journal 108(449), 1009-1025.

Gwartney, J. and Lawson, R. (2006), Economic Freedom of the World: 2006 Annual Report, Vancouver: The Fraser Institute.

Hairault, J.-O. (2002), 'Labor-market search and international business cycles', Review of Economic Dynamics 5, 535-558.

Hall, R. (2003), Wage determination and employment fluctuations, Working Paper 9967, NBER.

Hall, R. (2005), Job loss, job finding, and unemployment in the U.S. economy over the past fifty years, p. 101.

Hodrick, R. and Prescott, E. (1997), 'Post war us business cycles: an empirical investigation', Journal of Money, Credit and Banking 29, 1-16.

Ireland, P. (2001), 'Sticky-price models of the business cycle : Specification and stability', Journal of Monetary Economics 47, 3-18.

Ireland, P. (2003), 'Endogenous money or sticky prices?', Journal of Monetary Economics 50(8), 1623-1648. 
Ireland, P. (2004a), 'Money's role in the business cycle', Journal of Money, Credit and Banking 36(6), 969-83.

Ireland, P. (2004b), 'Technology shocks in the new Keynesian model', Review of Economics and Statistics 86(4), 923-936.

Karamé, F., Patureau, L. and Sopraseuth, T. (2008), 'Limited participation and exchange rate dynamics: Does theory meet the data?', Journal of Economic Dynamics and Control 32(8), 10411087.

Kashyap, A. and Mojon, B. (2003), Monetary Policy Transmission in the Euro Area: A Study by the Eurosystem Monetary Transmission Network, Cambridge University Press.

Keen, B. D. and Wang, Y. (2007), 'What is realistic value for price adjustment costs in new keynesian models?', Applied Economics Letters 14(11), 789-793.

Kim, S. (2001), 'International transmission of U.S. monetary policy shocks: Evidence from VAR's', Journal of Monetary Economics 48, 339-372.

Kollmann, R. (2001), 'Explaining international comovement of output and asset returns: The role of money and nominal rigidities', Journal of Economic Dynamics and Control 25, 1547-1583.

Krause, M. and Lubik, T. A. (2007), 'The (ir)relevance of real wage rigidity in the new keynesian model with search frictions', Journal of Monetary Economics 54(4), 706-727.

Kydland, F. and Prescott, E. (1982), 'Time to build and aggregate fluctuations', Econometrica 50, 1345-1370.

Lane, P. and Milesi-Ferretti, G. (2001), 'Long-term capital movements', NBER Macroeconomics Annual 16, 73-116.

Leeper, E. M., Sims, C. A. and Zha, T. (1996), 'What does monetary policy do?', Brookings Papers on Economic Activity 2, 1-63.

Nakamura, E. and Steinsson, J. (2008), 'Five facts about prices: A reevaluation of menu cost models', The Quarterly Journal of Economics 123(4), 1415-1464.

Nickell, W. (2006), The CEP - OECD Institutions dataset (1960-2004), Technical Report 07.

Obstfeld, M. and Rogoff, K. (1995), 'Exchange rate dynamics redux', Journal of Political Economy 103(3), 624-660.

Patureau, L. (2007), 'Pricing-to-market, limited participation and exchange rate dynamics', Journal of Economic, Dynamics and Control 31, 3281-3320.

Petrongolo, B. and Pissarides, C. A. (2001), 'Looking into the black box: A survey of the matching function', Journal of Economic Literature 39(2), 390-431.

Pissarides, C. (1990), Equilibrium Unemployment Theory, Basil Blackwell, Oxford. 
Poilly, C. and Sahuc, J.-G. (2008), Welfare implications of heterogeneous labor markets in a currency area, Manuscript, Banque de France.

Rabanal, P. and Tuesta, V. (2006), Euro-Dollar real exchange rate dynamics in an estimated twocountry model: What is important and what is not, Working Paper 06/177, IMF.

Rotemberg, J. (1982), 'Sticky prices in the United States', Journal of Political Economy 90, 11871211.

Schlagenhauf, D. and Wrase, J. (1995), 'Liquidity and real activity in a simple open-economy model', Journal of Monetary Economics 35(3), 431-461.

Schmitt-Grohe, S. and Uribe, M. (2003), 'Closing small open economy models', Journal of International Economics 61, 163-185.

Shimer, R. (2005), 'The cyclical behavior of equilibrium unemployment and vacancies', American Economic Review 95(1), 25-49.

Shimer, R. (2007), Reassessing the ins and outs of unemployment, Working Paper 13421, NBER.

Sveen, T. and Weinke, L. (2008), 'New Keynesian perspectives on labor market dynamics', Journal of Monetary Economics 55, 921-930.

Taylor, J. (1993), 'Discretion vs. policy rules in practice', Carnegie-Rochester Conference Series on Public Policy 39, 195-214.

Trigari, A. (2004), Equilibrium unemployment, job flows and inflation dynamics, Working paper 304, European Central Bank.

Walsh, C. (2005), 'Labor market search, sticky prices, and interest rate policies', Review of Economic Dynamics 8(4), 777-976.

Yashiv, E. (2007), 'Labor search and matching in macroeconomics', European Economic Review 51, 1859-1895. 


\section{A Data appendix: definitions and sources}

\section{A.1 Calibration}

Calibration of the labor market institutions values (Table 2) is made so as to match the corresponding average values observed in the United-States over the period 1980-2003, based on the dataset on Labor Market Institutions provided by Nickell (2006). Precisely, we respectively use the "direct tax rate" for $\tau^{w}$ and the "Employment tax rate" for $\tau^{f}$ (as denoted by Nickell). The calibration of $b / w h$ is based on the empirical ratio defined as the average across the five years of unemployment for three family situations and two money levels. Nickell's database provides other benefit replacement ratios, such as "brr 1 " that refers to the first year of unemployment benefits, averaged over three family situations and two earnings levels. Calibrating on this ratio would imply higher values than the one considered here. We investigate the role played by the degree of generosity of the unemployment benefit system in Section 5.

\section{A.2 Empirical business cycle properties}

This section details the sources of the empirical moments reported in Table 4. If not otherwise specified, within-country moments are based on own calculations, using quarterly OECD BSD database (taken in log and HP-filtered) over the period 1973:1-1998:4. Series for worked hours come from OECDstat. The correlation between unemployment and vacancies comes from Shimer (2005), based on US data over the period 1950-2001. The correlation between unemployment and inflation comes from Chéron and Langot (2000), based on US data over the period 1953:1-1990:3. Cross-country correlations of output, consumption and investment come from Kollmann (2001), as well as the nominal and real exchange rates volatilities, based on US data versus an aggregate of the non-US G7 countries for the period 1973:1-1994:3. The cross-country correlation of employment comes from Backus et al. (1995); it corresponds to the median value of a sample of 10 OECD countries versus the US, for the period 1970-mid 1990s. Persistence of nominal and real exchange rates come from Chari et al. (2002); it refers to exchange rates between the US and an aggregate of 9 European countries for the period 1973:1-2000:1.

\section{A.3 GDP comovement and product and labor market regulations}

This section details the definitions and sources of the variables used to obtain results in Table 6 . We use data coming from OECD databases (BSDB and Main Economic Indicators) to calculate the cross-country GDP correlation. We consider quarterly series of GDP (at factor cost), in volume at constant prices, over the period 1963:4-2003:4. 20 OECD countries are included in the sample: 
Australia, Austria, Belgium, Canada, Denmark, Finland, France, Germany, Ireland, Italy, Japan, the Netherlands, Norway, New Zealand, Portugal, Spain, Sweden, Switzerland, the United Kingdom, the United States. Data inspection suggests a structural break on German data due to the German reunification, and another one on French data due to May 1968's events (in 1968:2 and 1968:3) that the model cannot account for. Based on the methodology proposed by Milliard, Scott, and Sensier (1997), we detect outliers on the series converted into growth rates. This leads to identify one outlier for German series (1990:1) two for the French ones (1968:2 and 1968:3). The corresponding points in the series taken in growth rates are replaced by averaging the closest growth rates. The GDP series are then converted back into level. Bilateral correlations for the 190 country pairs of the sample are calculated on GDP series taken in log and filtered according to the Hodrick and Prescott (1997) methodology.

Data coming from the Fraser Institute are available on the website http://www. freetheworld.com. We use the 2005 edition of the Economic Freedom of the World Annual report. Variables are constructed to take values over the range $[0 ; 10]$, decreasing with the strength of regulation. Definition of the variables used in the regressions is the following.

- Unemployment Benefits Index: The indicator is constructed by Gwartney and Lawson (2006) using data from the World Competitiveness Yearbook published by the International Institute for Management Development. It indicates whether the unemployment benefits system preserves the incentive to work, with low values meaning that the unemployment benefit system has pernicious effects. Information is provided for years 1970, 1975, 1980, 1985, 1990, 1995, 2000, 2001 and 2003.

- EPL Index is measured using the "Hiring and Firing Practices" indicator, which is constructed using data from the Global Competitiveness Report published by the World Economic Forum. It indicates whether hiring and firing practices of companies are determined by private contract, with low values meaning that firing and hiring laws are more constraining. Information is provided for years 1990, 1995, 2000, 2001 and 2002.

- Price Rigidity Index is measured using the "Price Controls" Indicator which measures the extent to which businesses are free to set their own prices. It is constructed using survey data of the International Institute for Management Development (IMD), World Competitiveness Report. The more widespread the use of price controls, the lower the rating. Information on this variable is provided for years 1995, 2000, 2001 and 2003.

For each variable, we take the mean value of the period of data coverage for each country of the 
sample. This may be a concern for the EPL and Price Rigidity Indices, since the period coverage of both variables starts in the 1990s while they are aimed to explain the cross-country correlation over 1964-2003. This raises a potential problem of reversed causality. We do not view it as a serious concern though, since it is not likely to be the case that medium-run variables as GDP crosscorrelation affect the evolution of structural variables like product and labor market institutions. Besides, institutional variables typically display much lower time variabililty than macroeconomic variables such as GDP. However, we tried to address this problem by using series for institutional variables with an expanded time coverage. As for employment protection, we use the Employment Protection Indicator built by the OECD on a yearly basis starting in 1960 and provided by Nickell (2006). Preliminary experiments show that this variable is significant in simple OLS regression but not robust to the inclusion of country fixed effects. Nickell's dataset also provides some measures of product market regulations, but with data coverage starting in 1998 hence subject to similar concerns. As robustness check though, we run regressions using the "product market regulations" indicator provided by Nickell's database (denoted "pmr" in Nickell's database). We obtain similar results to those obtained with the Economic Freedom variables.

The computation of bilateral trade intensity is taken from the database provided by Darvas et al. (2005). It is available on Andrew Rose's web page: http://faculty.haas . berkeley .edu/arose/RecRes.htm. We use the measure of bilateral trade intensity, reported to the total of GDPs in both countries, averaged over the period 1964-2003 ("trdgdp1" in their database). The dummy variable controlling for adhesion to EMU takes the value 1 if the two countries of a given pair are among the following: Austria, Belgium, Finland, France, Germany, Ireland, Italy, the Netherlands, Portugal and Spain. 